\title{
A Family of Metal-Cyanide Cubes with Alternating Octahedral and Tetrahedral Corners Exhibiting a Variety of Magnetic Behaviors Including Single Molecule Magnetism
}

Eric J. Schelter, Ferdi Karadas, Carolina Avendano, Andrey V. Prosvirin, Wolfgang

\author{
Wernsdorfer and Kim R. Dunbar* \\ Department of Chemistry, Texas A\&M University, \\ P.O. Box 30012, College Station, TX 77842-3012 (USA) \\ E-mail:dunbar@mail.chem.tamu.edu
}

Supporting Information:

S1. Synthetic Details for 2-8.

S2. Scan rate dependences to the magnetization of 2 obtained using a micro-SQUID apparatus on easy-axis oriented single crystals. Magnetization values are normalized to the magnetization value at $1.4 \mathrm{~T}$.

S3. Field dependent magnetization data for $\left[\{\mathrm{MnI}\}_{4}\left\{\operatorname{Re}(\text { triphos })(\mathrm{CN})_{3}\right\}_{4}\right](3)$.

S4. AC susceptibility studies of $\left[\{\mathrm{MnI}\}_{4}\left\{\operatorname{Re}(\text { triphos })(\mathrm{CN})_{3}\right\}_{4}\right]$ (3) from 1.8-5 K.

S5. Field dependent magnetization data for $\left[\{\mathrm{FeCl}\}_{4}\left\{\operatorname{Re}(\text { triphos })(\mathrm{CN})_{3}\right\}_{4}\right](4)$ collected at $1.8 \mathrm{~K}$.

S6. Temperature dependent susceptibility of $\left[\{\mathrm{FeCl}\} 3.5\{\mathrm{Fe}(\mathrm{OCH})(\mathrm{THF})\}_{0.5-}\right.$ $\left\{\operatorname{Re}(\right.$ triphos $\left.\left.)(\mathrm{CN})_{3}\right\} 4\right]$ (5).

S7. Crystallographic Experimental Details

S8. Table of structural parameters for $\left[\{\mathrm{FeCl}\} 3.5\left\{\mathrm{Fe}\left(\mathrm{OCH}_{3}\right)(\mathrm{THF})\right\} 0.5-\right.$ $\left\{\operatorname{Re}(\right.$ triphos $\left.\left.)(\mathrm{CN})_{3}\right\} 4\right](5)$.

S9. Molecular structure of $\left[\{\mathrm{NiCl}\}_{4}\left\{\operatorname{Re}(\text { triphos })(\mathrm{CN})_{3}\right\}_{4}\right](7)$.

S10. Table of structural parameters for $\left[\{\mathrm{NiCl}\}_{4}\left\{\operatorname{Re}(\operatorname{triphos})(\mathrm{CN})_{3}\right\}_{4}\right](7)$.

S11. Selected bond angles for $\left[\{\mathrm{ZnCl}\}_{4}\left\{\operatorname{Re}(\text { triphos })(\mathrm{CN})_{3}\right\}_{4}\right](\mathbf{8})$.

S12. Field dependent magnetization data for $\left[\{\mathrm{ZnCl}\}_{4}\left\{\operatorname{Re}(\text { triphos })(\mathrm{CN})_{3}\right\}_{4}\right](\mathbf{8})$ collected at $1.8 \mathrm{~K}$. 
S1. Synthetic Details for 2-8.

$\left[\{\mathbf{M n C l}\}_{4}\left\{\operatorname{Re}(\text { triphos })(\mathbf{C N})_{3}\right\}_{4}\right] \quad$ (2). $\left[\mathrm{Et}_{4} \mathrm{~N}\right]\left[\operatorname{Re}(\right.$ triphos $\left.)(\mathrm{CN})_{3}\right](0.220 \mathrm{~g}, 0.216 \mathrm{mmol})$ was dissolved in a mixture of $16 \mathrm{~mL}$ acetone and $8 \mathrm{~mL}$ acetonitrile yielding a bright, canary-yellow solution. A mixture of $5 \mathrm{~mL}$ acetone and $3 \mathrm{~mL}$ acetonitrile were added to $\mathrm{MnCl}_{2}$ (anhydrous) $(0.027 \mathrm{~g}, 0.215 \mathrm{mmol})$ in a separate flask yielding a white suspension with stirring. The yellow solution was then transferred via cannula to the white suspension resulting in an immediate color change to red-orange. The reaction mixture was then stirred at refluxed for $12 \mathrm{~h}$, with an orange-red microcrystalline product becoming evident after $1 / 2$ hour. After reflux the solution was allowed to cool and microcrystalline product collected by filtration. The product was then washed with acetone $(3 \times 5 \mathrm{~mL})$, copious amounts of acetonitrile, and diethyl ether $(3 \times 5 \mathrm{~mL})$, and dried in air. Yield $0.122 \mathrm{~g}(0.031 \mathrm{mmol}), 55 \%$. Anal. Calc'd for 2, $\mathrm{C}_{176} \mathrm{H}_{156} \mathrm{~N}_{12} \mathrm{Cl}_{4} \mathrm{P}_{12} \mathrm{Fe}_{4} \mathrm{Re}_{4}:$ C, 53.96; H, 4.01; N, 4.29; Cl, 3.62. Found: C, 53.49; H, 4.05; $\mathrm{N}, 4.33 ; \mathrm{Cl}, 3.35 . \mathrm{IR}(\mathrm{Nujol}): \mathrm{v}=2100,2085 \mathrm{~cm}^{-1}(\mathrm{C} \equiv \mathrm{N}) ; \mathrm{ES}^{+}-\mathrm{MS}\left(\mathrm{CH}_{3} \mathrm{CN} / \mathrm{CH}_{2} \mathrm{Cl}_{2} 1: 1\right.$ mixture $) \mathrm{m} / \mathrm{z}=1939.16\left([\mathrm{M}-\mathrm{Cl}]^{2+}\right), 1921.18\left([\mathrm{M}-2 \mathrm{Cl}]^{2+}\right), 1268.80\left([\mathrm{M}-3 \mathrm{Cl}]^{3+}\right) . \mathrm{UV}-$ $\operatorname{Vis}\left(\mathrm{CH}_{2} \mathrm{Cl}_{2}\right): \lambda_{\max }, \mathrm{nm}\left(\varepsilon\right.$ in $\left.M^{-1} \mathrm{~cm}^{-1}\right)=479(6200)$.

$\left[\{\mathbf{M n I}\}_{4}\left\{\operatorname{Re}(\text { triphos })(\mathbf{C N})_{3}\right\}_{4}\right]$ (3). The synthesis of 3 is identical to that of 2 with the substitution of anhydrous $\mathrm{MnI}_{2}$ for $\mathrm{MnCl}_{2}$. Analytically pure product was obtained by recrystallization of the red-orange solid from $\mathrm{CH}_{2} \mathrm{Cl}_{2} / \mathrm{EtOH}$. Yield $0.052 \mathrm{~g}(0.012$ mmol), $14 \%$. Anal. Calc'd for 3, $\mathrm{C}_{176} \mathrm{H}_{156} \mathrm{~N}_{12} \mathrm{I}_{4} \mathrm{P}_{12} \mathrm{Fe}_{4} \mathrm{Re}_{4}: \mathrm{C}, 49.41 ; \mathrm{H}, 3.83 ; \mathrm{N}, 3.87$. Found: C, 49.35; H, 3.67; N, 3.92. IR(Nujol): $v=2096,2081 \mathrm{~cm}^{-1}(\mathrm{C} \equiv \mathrm{N}) ; \mathrm{ES}^{+}-\mathrm{MS}$ $\left(\mathrm{CH}_{3} \mathrm{CN} / \mathrm{CH}_{2} \mathrm{Cl}_{2} 1: 1\right.$ mixture $) \mathrm{m} / \mathrm{z}=2078\left([\mathrm{M}-\mathrm{I}]^{2+}\right), 2014\left([\mathrm{M}-2 \mathrm{I}]^{2+}\right), 1301([\mathrm{M}-$ $\left.3 \mathrm{I}]^{3+}\right)$. UV-Vis $\left(\mathrm{CH}_{2} \mathrm{Cl}_{2}\right): \lambda_{\max }, \mathrm{nm}\left(\varepsilon\right.$ in $\left.M^{-1} \mathrm{~cm}^{-1}\right)=481(8500)$. 
$\left[\{\mathbf{F e C l}\}_{4}\left\{\operatorname{Re}(\text { triphos })(\mathbf{C N})_{3}\right\}_{4}\right]$ (4). $\left[\mathrm{Et}_{4} \mathrm{~N}\right]\left[\operatorname{Re}(\right.$ triphos $\left.)(\mathrm{CN})_{3}\right](0.080 \mathrm{~g}, 0.078 \mathrm{mmol})$ was dissolved in $5 \mathrm{~mL}$ of dry acetonitrile to yield a canary-yellow solution. This was treated with $\mathrm{Fe}_{4} \mathrm{Cl}_{8}(\mathrm{THF})_{6}(0.032 \mathrm{~g}, 0.034 \mathrm{mmol})$ dissolved in $4 \mathrm{~mL}$ of acetonitrile and $1 \mathrm{~mL}$ of diethyl ether which led to an instantaneous color change to dark blue. After 18 hours, a crystalline blue product was harvested by vacuum filtration in air. The solid was washed with acetonitrile $(3 \times 5 \mathrm{~mL})$ followed by diethyl ether $(3 \times 5 \mathrm{~mL})$ and air-dried. Yield: $0.053 \mathrm{~g}(63 \%)$. Anal. Calc'd for 4, $\mathrm{C}_{176} \mathrm{H}_{156} \mathrm{~N}_{12} \mathrm{Cl}_{4} \mathrm{P}_{12} \mathrm{Fe}_{4} \mathrm{Re}_{4}$ : C, 53.91; H, 4.01; N, 4.23; $\mathrm{Cl}$, 3.62. Found: $\mathrm{C}, 53.52 ; \mathrm{H}, 4.12 ; \mathrm{N}, 4.19 ; \mathrm{Cl}, 3.52$. IR(Nujol): $\mathrm{v}=2011,1992 \mathrm{~cm}^{-1}$ $(\mathrm{C} \equiv \mathrm{N})$; Mössbauer $(77.5 \mathrm{~K}): \mathbf{1}: \delta=0.43 \mathrm{~mm} \mathrm{~s}^{-1}$ (relative to $\mathrm{RT} F$ ), $\Delta \mathrm{E}=0.53 \mathrm{~mm} \mathrm{~s}^{-1}$. $\mathrm{ES}^{+}-\mathrm{MS}\left(\mathrm{CH}_{3} \mathrm{CN} / \mathrm{CH}_{2} \mathrm{Cl}_{2}\right.$ 1:1 mixture): $\mathrm{m} / \mathrm{z}=1960.10\left([\mathrm{M}]^{2+}\right) . \quad \mathrm{UV}-\mathrm{Vis}\left(\mathrm{CH}_{2} \mathrm{Cl}_{2}\right): \lambda_{\max }$, $\mathrm{nm}\left(\varepsilon\right.$ in $\left.M^{-1} \mathrm{~cm}^{-1}\right)=707(67,000)$.

\section{$\left[\{\mathbf{F e C l}\}_{3.5}\left\{\mathbf{F e}\left(\mathrm{OCH}_{3}\right)(\mathrm{THF})\right\}_{0.5}\left\{\operatorname{Re}(\text { triphos })(\mathrm{CN})_{3}\right\}_{4}\right] \quad$ (5). $\quad\left[\mathrm{Et}_{4} \mathrm{~N}\right]\left[\operatorname{Re}(\right.$ triphos $\left.)(\mathrm{CN})_{3}\right]$}

$(0.151 \mathrm{~g}, 0.142 \mathrm{mmol})$ was dissolved in $10 \mathrm{~mL}$ of a $1: 1: 1(\mathrm{v} / \mathrm{v})$ mixtue acetonitrile, acetone, and $\mathrm{MeOH}$ to yield a canary-yellow solution. This was slowly cannulated to a solution of $\mathrm{Fe}_{4} \mathrm{Cl}_{8}(\mathrm{THF})_{6}(0.034 \mathrm{~g}, 0.036 \mathrm{mmol})$ dissolved in $10 \mathrm{~mL}$ of a $1: 1: 1(\mathrm{v} / \mathrm{v})$ mixture of acetonitrile, tetrahydrofuran, and methanol with stirring which led to an instantaneous color change to dark blue. Shiny, blue, microcrystalline product precipitated from the dark blue solution after $\sim 10$ minutes of stirring. The solution was stirred for $16 \mathrm{~h}$ and a shiny, dark blue solid collected by vacuum filtration in air. The product was washed with $3 \times 5 \mathrm{~mL}$ acetonitrile, $5 \mathrm{~mL}$ diethyl ether, and air-dried. Yield 0.060 g (39\%). Anal. Calc'd for 5, $\mathrm{C}_{178.5} \mathrm{H}_{167} \mathrm{~N}_{12} \mathrm{Cl}_{3.5} \mathrm{OP}_{12} \mathrm{Fe}_{4} \mathrm{Re}_{4}: \mathrm{C}, 54.21 ; \mathrm{H}, 4.12 ; \mathrm{N}$, 4.25; Cl, 3.14. Found: C, 53.27; H, 4.07; N, 4.30; Cl, 3.70. IR(Nujol): $v=2010$ and $1990 \mathrm{~cm}^{-1}(\mathrm{C} \equiv \mathrm{N}) . \mathrm{ES}^{+}-\mathrm{MS}\left(\mathrm{CH}_{3} \mathrm{CN} / \mathrm{CH}_{2} \mathrm{Cl}_{2}\right.$ 1:1 mixture $): \mathrm{m} / \mathrm{z}=1943\left(\left[\mathrm{M}-\mathrm{CH}_{3} \mathrm{O}^{-}-\right.\right.$ 
$\left.\left.\mathrm{C}_{2} \mathrm{H}_{8} \mathrm{O}\right]^{2+}\right), 1960\left([4]^{2+}\right)$, and $1973\left(\left[\mathrm{M}-\left(\mathrm{C}_{2} \mathrm{H}_{8} \mathrm{O}\right)+\left(\mathrm{CH}_{3} \mathrm{O}^{-}\right)\right]^{2+}\right) . \mathrm{UV}-\mathrm{Vis}\left(\mathrm{CH}_{2} \mathrm{Cl}_{2}\right): \lambda_{\max }$, $\mathrm{nm}\left(\varepsilon\right.$ in $\left.M^{-1} \mathrm{~cm}^{-1}\right)=709(58,000)$.

$\left[\{\mathrm{CoCl}\}_{4}\left\{\operatorname{Re}(\text { triphos })(\mathrm{CN})_{3}\right\}_{4}\right]$ (6). The synthesis of 6 is identical to that of 4 except the acetonitrile washings were minimized due to higher solubility of 6 . Yield $0.097 \mathrm{~g}(0.025$ mmol), (65\%). Anal. Calc'd for 6, $\mathrm{C}_{176} \mathrm{H}_{156} \mathrm{~N}_{12} \mathrm{Cl}_{4} \mathrm{P}_{12} \mathrm{Co}_{4} \mathrm{Re}_{4}$ : C, 53.74; H, 4.00; N, 4.27; $\mathrm{Cl}$, 3.61. Found: C, 53.89; H, 4.16; N, 4.12; Cl, 3.58. IR(Nujol): $v=2111,2096 \mathrm{~cm}^{-1}$ $(\mathrm{C} \equiv \mathrm{N}) . \mathrm{ES}^{+}-\mathrm{MS}\left(\mathrm{CH}_{3} \mathrm{CN} / \mathrm{CH}_{2} \mathrm{Cl}_{2}\right.$ 1:1 mixture $): \mathrm{m} / \mathrm{z}=1966.19\left([\mathrm{M}]^{2+}\right), 1947.20([\mathrm{M}-$ $\left.\mathrm{Cl}]^{2+}\right), 1930.20\left([\mathrm{M}-2 \mathrm{Cl}]^{2+}\right) . \mathrm{UV}-\mathrm{Vis}\left(\mathrm{CH}_{2} \mathrm{Cl}_{2}\right): \lambda_{\max }, \mathrm{nm}\left(\varepsilon\right.$ in $\left.M^{-1} \mathrm{~cm}^{-1}\right)=478.5(7800)$, $614(6400)$

$\left[\left\{\mathbf{N i C l}_{4}\left\{\mathbf{R e}(\text { triphos})(\mathbf{C N})_{3}\right\}_{4}\right]\right.$ (7). $5 \mathrm{~mL}$ dry acetonitrile was added to $0.033 \mathrm{~g}(\sim 0.25$ mmol) $\mathrm{NiCl}_{2}$ (anhydrous) yielding a clear, colorless solution with an light yellow suspended solid with stirring. $5 \mathrm{~mL}$ dry acetonitrile was then added to $0.260 \mathrm{~g}(\sim 0.26$ mmol) $\left[\mathrm{Et}_{4} \mathrm{~N}\right]\left[\operatorname{Re}(\operatorname{triphos})(\mathrm{CN})_{3}\right]$ which dissolved with stirring and slight heating to yield a clear, bright-yellow solution. The yellow rhenium solution was then transferred via cannula to the light yellow suspension, washing the Schlenk tube and cannula with an additional $5 \mathrm{~mL}$ dry acetonitrile, to yield a dark green mixture. The mixture was stirred and refluxed over $5 \mathrm{~h}$, during which time a brown, microcrystalline precipitate was observed to form. After $5 \mathrm{~h}$, the brown solid was isolated from the dark brown solution by filtration in air and washed with copious amounts of acetonitrile. The solid was then air-dried and collected. Yield $0.20 \mathrm{~g}(0.047 \mathrm{mmol})$, 74\%. Anal. Calc'd for 7, $\mathrm{C}_{176} \mathrm{H}_{156} \mathrm{~N}_{12} \mathrm{Cl}_{4} \mathrm{P}_{12} \mathrm{Ni}_{4} \mathrm{Re}_{4}: \mathrm{C}, 53.76 ; \mathrm{H}, 4.00 ; \mathrm{N}, 4.27 ; \mathrm{Cl}, 3.61$. Found: C, 53.39; H, 4.14; $\mathrm{N}, 4.46 ; \mathrm{Cl}, 3.28$. IR(Nujol): $v=2122,2109 \mathrm{~cm}^{-1}(\mathrm{C} \equiv \mathrm{N}) ; \mathrm{ES}^{+}-\mathrm{MS}\left(\mathrm{CH}_{3} \mathrm{CN} / \mathrm{CH}_{2} \mathrm{Cl}_{2}\right.$ 1:1 
mixture): $m / z=1946.33\left([\mathrm{M}-\mathrm{Cl}]^{2+}\right), 1930.30\left([\mathrm{M}-2 \mathrm{Cl}]^{2+}\right), 1275.22\left([\mathrm{M}-3 \mathrm{Cl}]^{3+}\right) . \mathrm{UV}-$ $\operatorname{Vis}\left(\mathrm{CH}_{2} \mathrm{Cl}_{2}\right): \lambda_{\max }, \mathrm{nm}\left(\varepsilon\right.$ in $\left.M^{-1} \mathrm{~cm}^{-1}\right)=401(9700), 478(8300)$.

$\left[\{\mathbf{Z n C l}\}_{4}\left\{\operatorname{Re}(\text { triphos })(\mathbf{C N})_{3}\right\}_{4}\right]$ (8). In a nitrogen atmosphere dry box, $0.260 \mathrm{~g}(\sim 0.26$ mmol) $\left[\mathrm{Et}_{4} \mathrm{~N}\right]\left[\operatorname{Re}(\right.$ triphos $\left.)(\mathrm{CN})_{3}\right]$ was loaded into a Schlenk tube and $0.034 \mathrm{~g}(\sim 0.25$ mmol) $\mathrm{ZnCl}_{2}$ (anhydrous) was loaded into a pear-shaped $250 \mathrm{~mL}$ Schlenk flask. Both flasks were then installed on a Schlenk line and purged three times with $\mathrm{N}_{2} /$ vacuum. The $\mathrm{ZnCl}_{2}(\mathrm{~s})$ was dissolved in $5 \mathrm{~mL}$ and the $\left[\mathrm{Et}_{4} \mathrm{~N}\right]\left[\operatorname{Re}(\right.$ triphos $\left.)(\mathrm{CN})_{3}\right] 10 \mathrm{~mL}$ of a $1: 1 \mathrm{v} / \mathrm{v}$ solution of acetonitrile/acetone yielding clear, colorless and clear, yellow solutions respectively. The $\mathrm{ZnCl}_{2}$ solution was then transferred via a cannula needle to the yellow solution of rhenium resulting in the immediate appearance of a red color, which quickly disappeared with stirring. After the $\mathrm{ZnCl}_{2}$ solution was transferred, the resulting solution appeared yellow with a greenish tinge. The mixture was then brought to reflux and after $1 \mathrm{hr}$ appeared a yellow, microcrystalline solid. The mixture was refluxed for $12 \mathrm{~h}$. The yellow product was collected by vacuum filtration in air and washed with three times with minimal amounts of methanol (in which the product is sparingly soluble), acetone (3 $\times 5 \mathrm{~mL})$, and diethyl ether $(3 \times 5 \mathrm{~mL})$. The solid product was dried in air and appeared tan with an orange tinge when dry. Yield $0.068 \mathrm{~g}(0.017 \mathrm{mmol}), 27 \%$. Anal. Calc'd for 8, $\mathrm{C}_{176} \mathrm{H}_{156} \mathrm{~N}_{12} \mathrm{Cl}_{4} \mathrm{P}_{12} \mathrm{Re}_{4} \mathrm{Zn}_{4}:$ C, 53.39; H, 3.97; N, 4.25. Found: C, 53.06; H, 4.11; N, 4.32. IR(Nujol): $v=2127,2115,2102,2074 \mathrm{~cm}^{-1}(\mathrm{C} \equiv \mathrm{N})$. ESI-MS $\left(\mathrm{CH}_{3} \mathrm{CN} / \mathrm{CH}_{2} \mathrm{Cl}_{2} \quad 1: 1\right.$ mixture) $\mathrm{m} / \mathrm{z}=1943.19\left([\mathrm{M}-2 \mathrm{Cl}]^{2+}\right), 1952.19\left(\left[\mathrm{M}-2 \mathrm{Cl}+\mathrm{H}_{2} \mathrm{O}\right]^{2+}\right), 1961.00([\mathrm{M}-2 \mathrm{Cl}+$ $\left.\left.2 \mathrm{H}_{2} \mathrm{O}\right]^{2+}\right), 1923.24\left([\mathrm{M}-3 \mathrm{Cl}]^{2+}\right), 1931.72\left(\left[\mathrm{M}-3 \mathrm{Cl}+\mathrm{H}_{2} \mathrm{O}\right]^{2+}\right), 1894.24([\mathrm{M}-4 \mathrm{Cl}-$ $\left.\mathrm{CN}]^{2+}\right), 1903.00\left(\left[\mathrm{M}-4 \mathrm{Cl}-\mathrm{CN}+\mathrm{H}_{2} \mathrm{O}\right]^{2+}\right), 1912.00\left(\left[\mathrm{M}-4 \mathrm{Cl}-\mathrm{CN}+2 \mathrm{H}_{2} \mathrm{O}\right]^{2+}\right) . \quad \mathrm{UV}-$ $\operatorname{Vis}\left(\mathrm{CH}_{2} \mathrm{Cl}_{2}\right): \lambda_{\max }, \mathrm{nm}\left(\varepsilon\right.$ in $\left.M^{-1} \mathrm{~cm}^{-1}\right)=477$ (6000). 

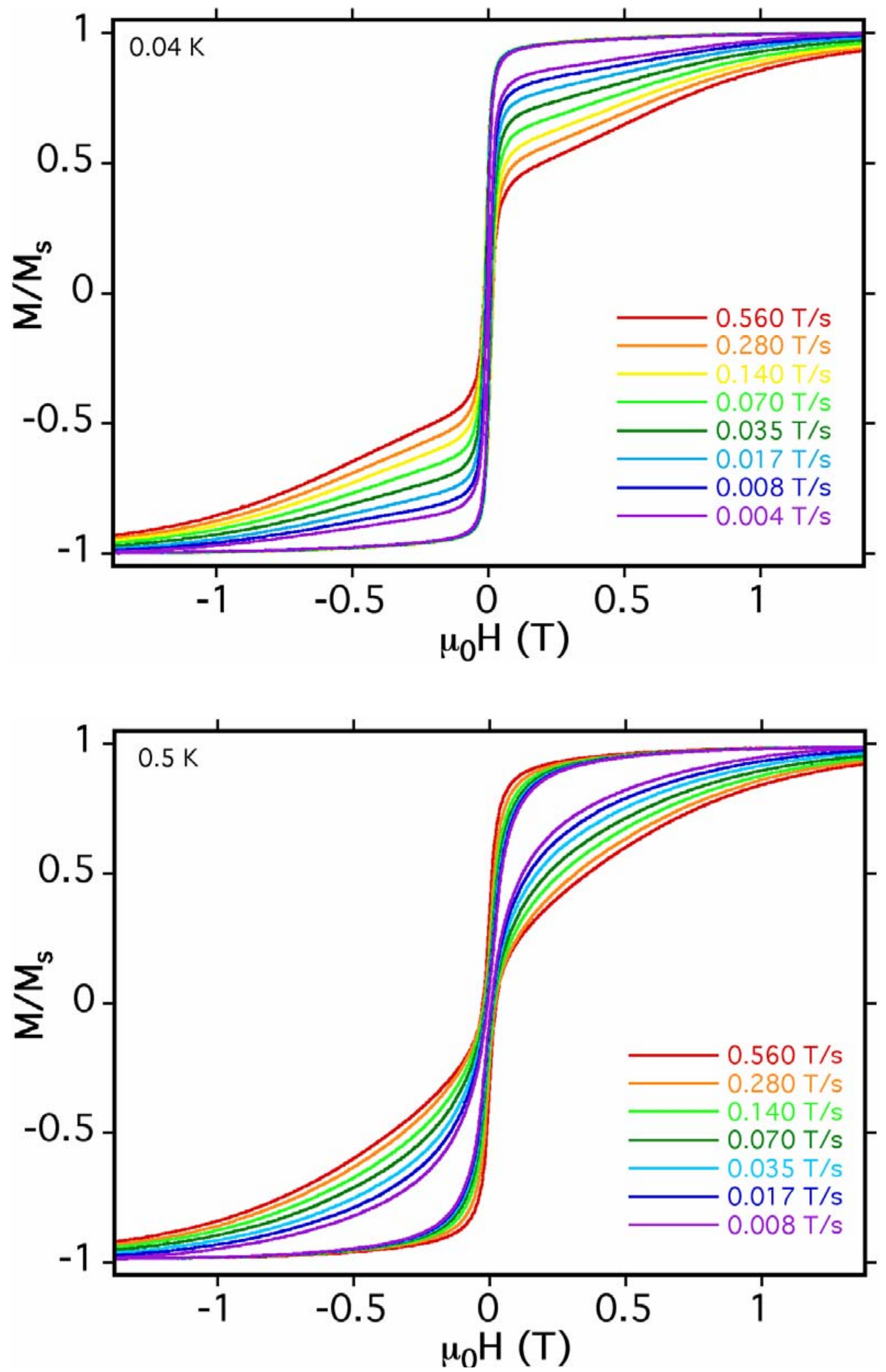

S2. Scan rate dependences to the magnetization of $\left[\{\mathrm{MnCl}\}_{4}\left\{\mathrm{Re}(\text { triphos })(\mathrm{CN})_{3}\right\}_{4}\right]$ (2) obtained using a micro-SQUID apparatus on easy-axis oriented single crystals. Magnetization values are normalized to the magnetization value at $1.4 \mathrm{~T}$. 


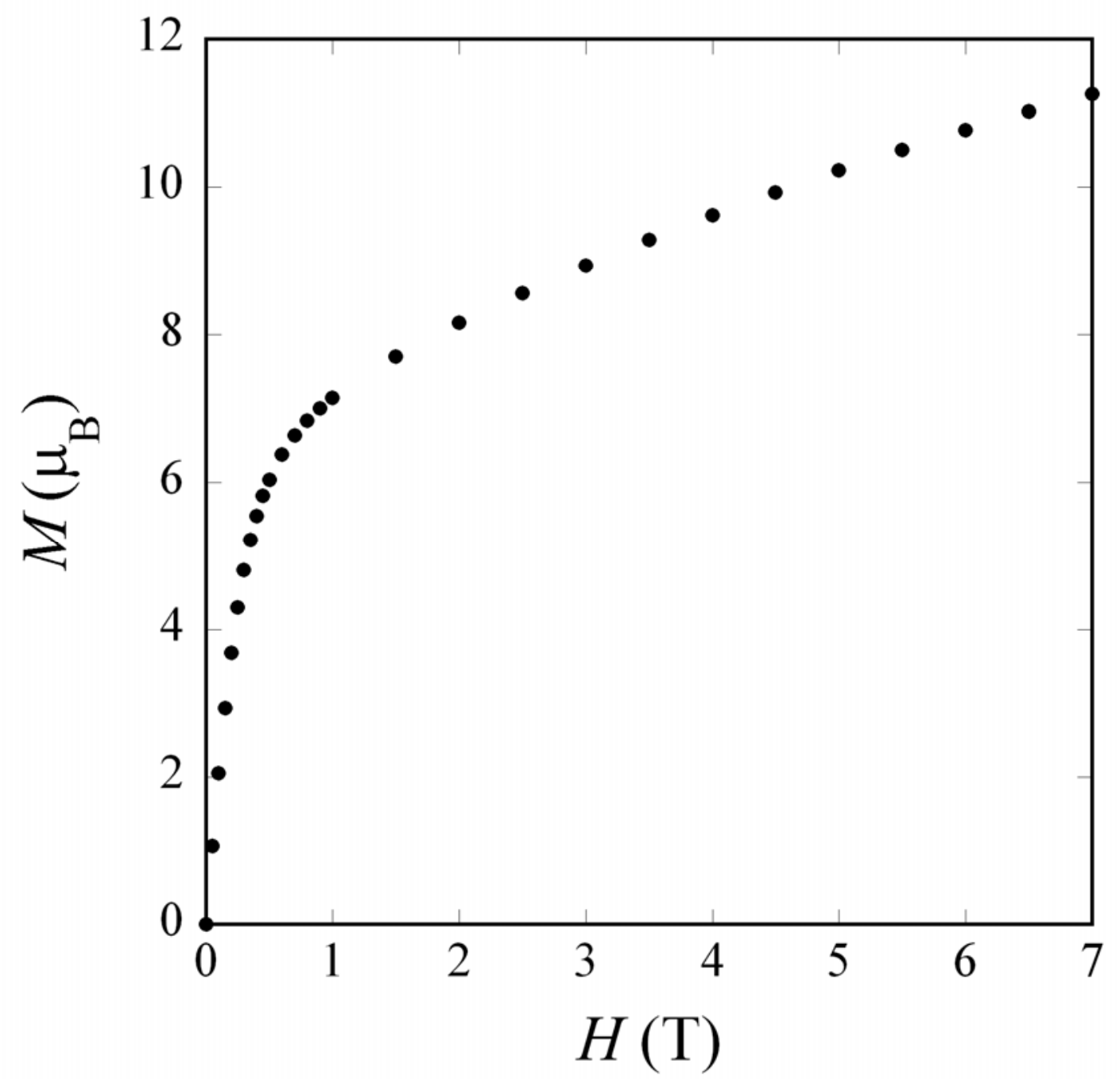

S3. Field dependent magnetization data for $\left[\{\mathrm{MnI}\}_{4}\left\{\operatorname{Re}(\text { triphos })(\mathrm{CN})_{3}\right\}_{4}\right]$ (3) collected at $1.8 \mathrm{~K}$ - The high field value of $11.26 \mu_{\mathrm{B}}$ obtained in this experiment is significantly less than the expected value for $S=8\left(16 \mu_{\mathrm{B}}\right)$, and the high field response of the complex does not saturate. These points are justified by noting the orbital contribution of the Re ${ }^{\mathrm{II}}$ ion, which results in the cluster having $g<2$. Complete sweep of the field in the positive and negative directions in this experiment reveals the compound does not exhibit coercivity at $1.8 \mathrm{~K}$. 

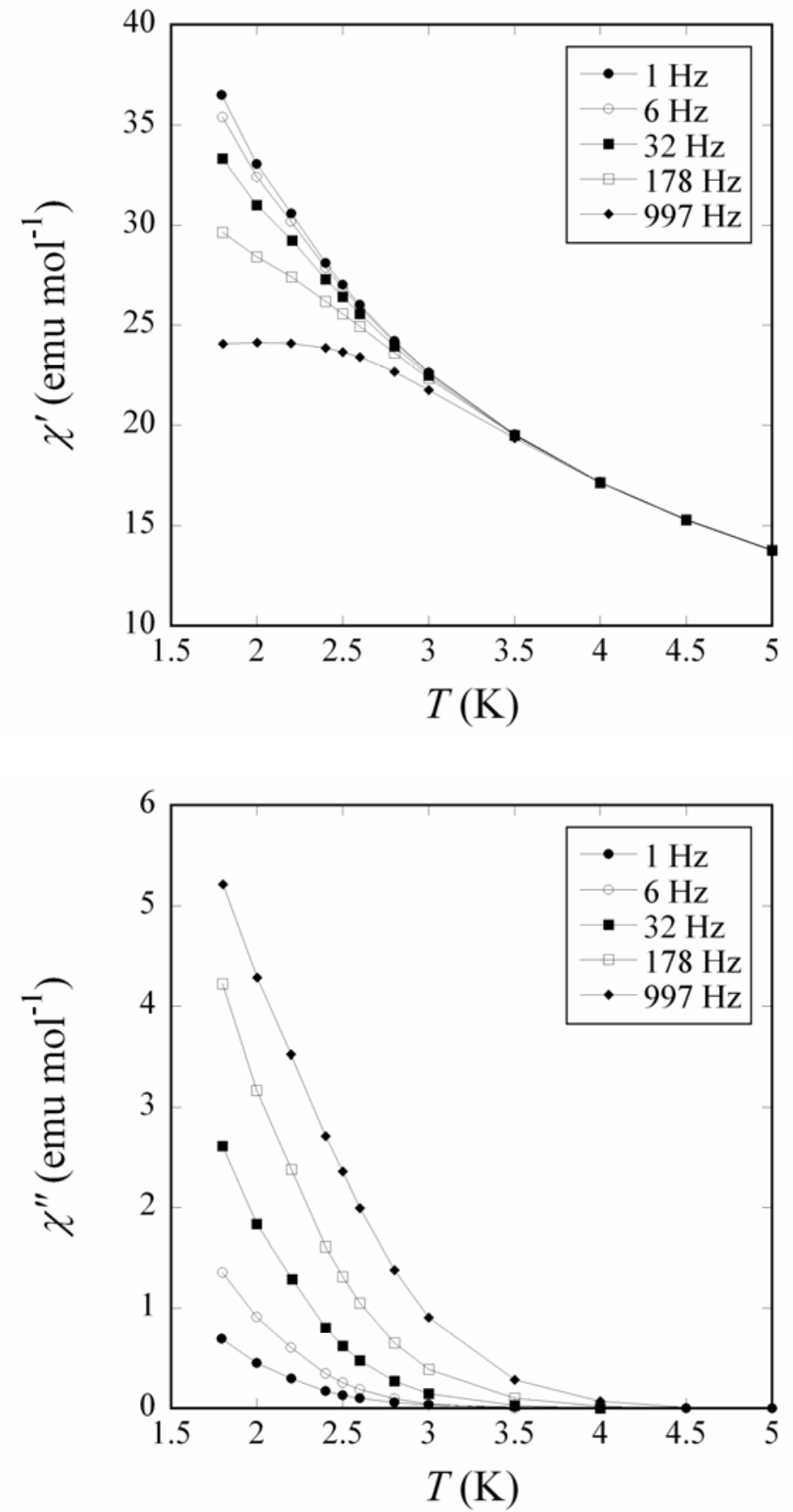

S4. AC susceptibility studies of $\left[\{\mathrm{MnI}\}_{4}\left\{\operatorname{Re}(\text { triphos })(\mathrm{CN})_{3}\right\}_{4}\right]$ (3) from 1.8-5 K with $\mathrm{H}=$ 0 Oe. 


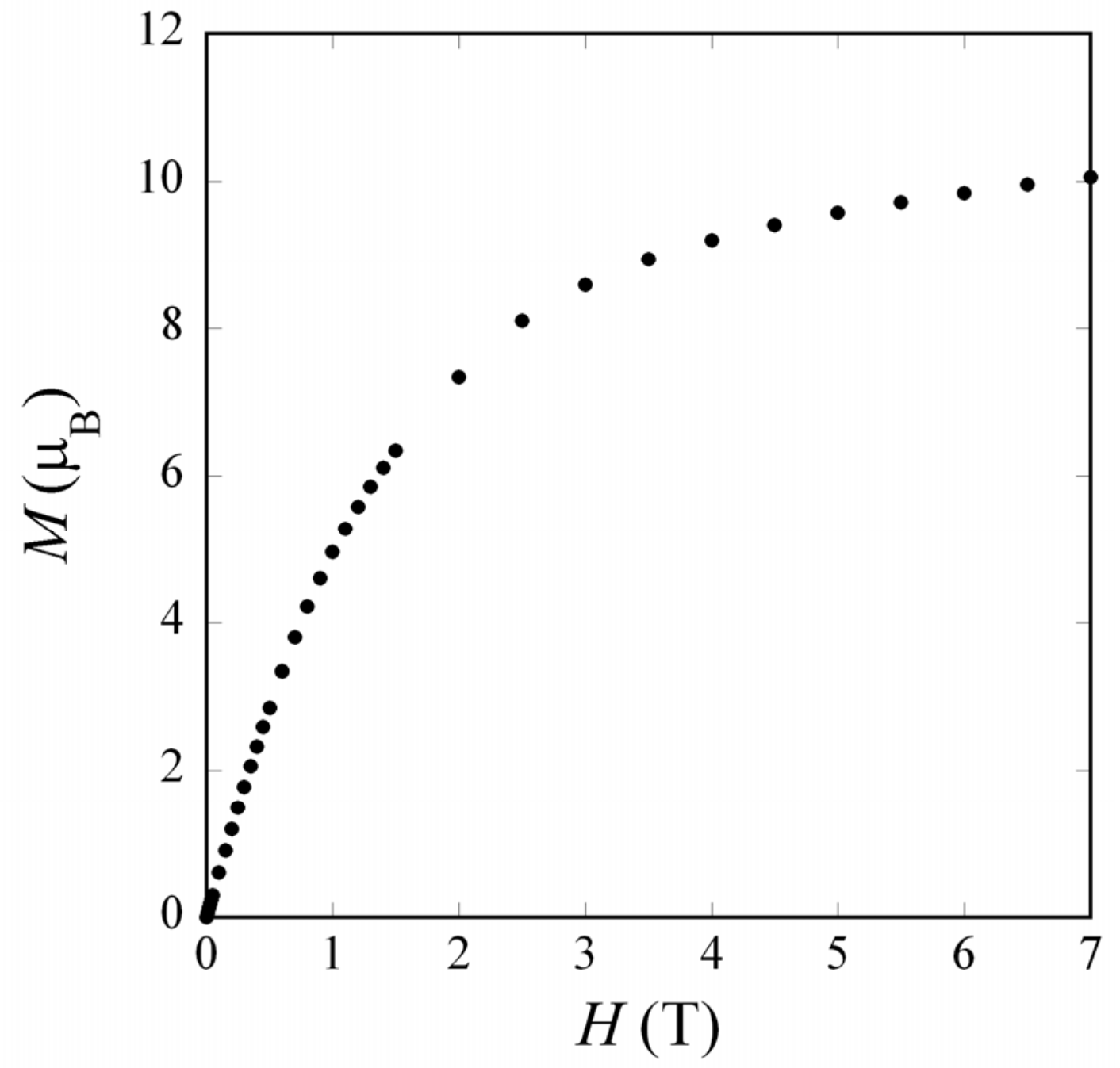

S5. Field dependent magnetization data for $\left[\{\mathrm{FeCl}\}_{4}\left\{\operatorname{Re}(\text { triphos })(\mathrm{CN})_{3}\right\}_{4}\right](4)$ collected at $1.8 \mathrm{~K}$. 


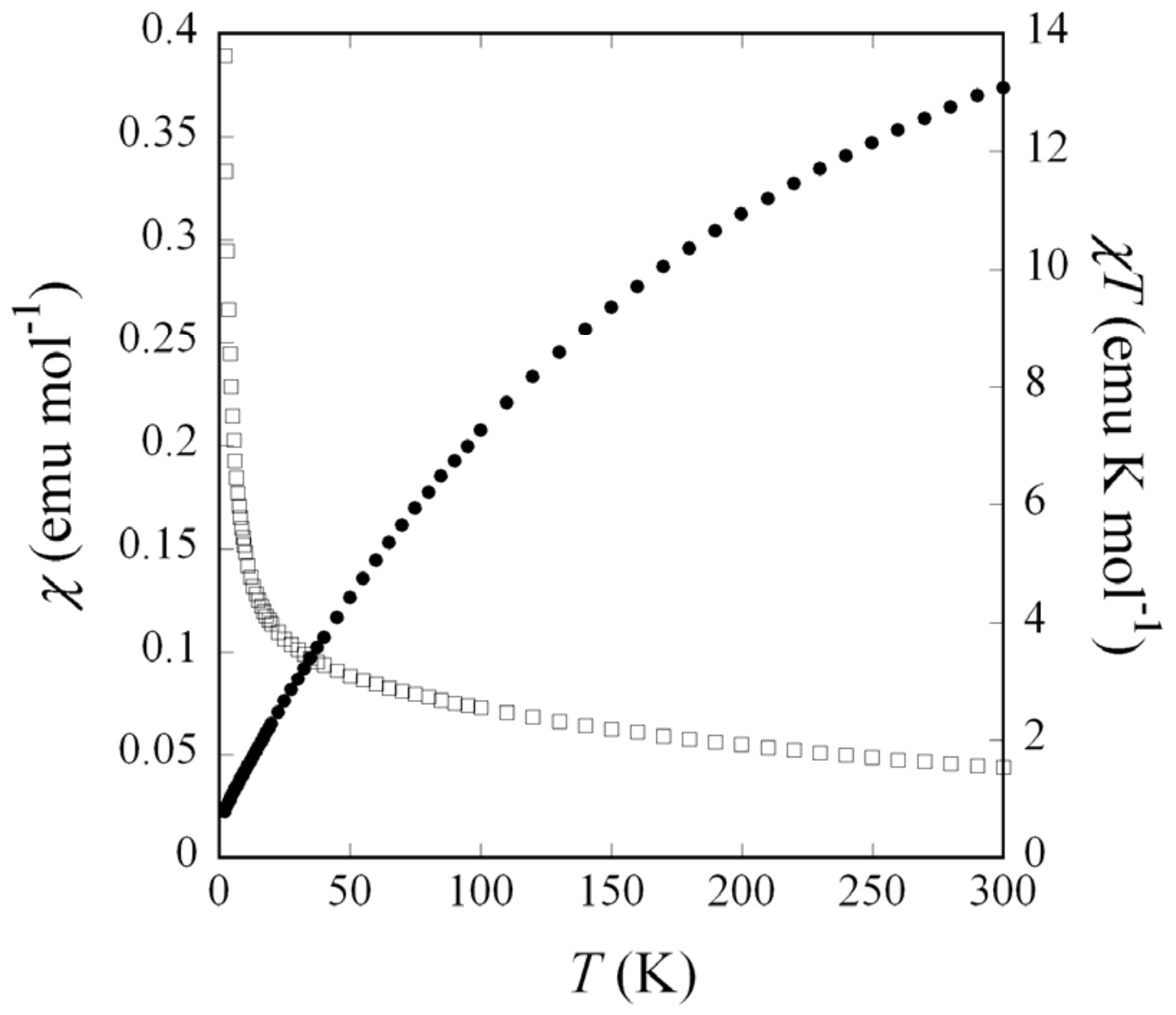

S6. Temperature dependent susceptibility of $\left[\{\mathrm{FeCl}\} 3.5\left\{\mathrm{Fe}\left(\mathrm{OCH}_{3}\right)(\mathrm{THF})\right\}_{0.5}\left\{\mathrm{Re}(\right.\right.$ triphos $\left.\left.)(\mathrm{CN})_{3}\right\} 4\right]$ (5). The nature of the magnetic behavior of 5 is similar to compound 4 , possessing a gradual, curving descent for $\chi_{m} T$ over the entire temperature range from $300-2 \mathrm{~K}$. The substitutional disorder present in 5 modifies the magnetic ground state of this compound only slightly. Compound $\mathbf{5}$ exhibits a high temperature magnetic moment of $13.08 \mathrm{emu} \mathrm{K} \mathrm{mol}{ }^{-1}$, which corresponds to a magnetic moment per $\mathrm{Fe}^{\mathrm{III}}$ center of $5.11 \mu_{\mathrm{B}}$. At low temperatures the moment decreases until it reaches a value of $0.7786 \mathrm{emu} \mathrm{K} \mathrm{mol}{ }^{-1}\left(2.50 \mu_{\mathrm{B}}\right)$, which is slightly less than the observed value for $\mathbf{4}$ at the same temperature. Based on infrared spectroscopic data, the same conclusions can be drawn about the magnetic ground states of $\mathbf{4}$ and $\mathbf{5}$, that is, the temperature dependent behavior of $\mathbf{5}$ is most likely arising from a combination of ZFS of the $\mathrm{Fe}^{\mathrm{III}}$ ion, TIP from the $\mathrm{Re}^{\mathrm{I}}$ centers, and next-nearest neighbor magnetic coupling interactions between the $\mathrm{Fe}^{\mathrm{III}}$ centers. 
S7. Crystallographic Experimental Details

$\left\{[\mathrm{FeCl}]_{3.5}\left[\mathrm{Fe}\left(\mathrm{OCH}_{3}\right)(\mathrm{THF})\right]_{0.5}\left[\operatorname{Re}(\text { triphos })(\mathrm{CN})_{3}\right]_{4}\right\} \quad$ (5): Large, single, plate-like crystals suitable for single crystal X-ray diffraction analysis were grown by layering a solution of $\left[\mathrm{Et}_{4} \mathrm{~N}\right]\left[\operatorname{Re}(\right.$ triphos $\left.)(\mathrm{CN})_{3}\right]$ dissolved in acetonitrile with a solution of $\mathrm{Fe}_{4} \mathrm{Cl}_{8}(\mathrm{THF})_{6}$ dissolved in a mixture of acetonitrile and methanol in a $4 \mathrm{~mm}$ diameter glass tube. A dark blue plate of approximate dimensions $0.57 \times 0.27 \times 0.16 \mathrm{~mm}^{3}$ was affixed to a nylon loop using Paratone mineral oil and data were measured at 100(2) K on a Siemens SMART CCD diffractometer (APEX detector) with graphite monochromated Mo-K $\alpha\left(\lambda_{\alpha}=0.71073 \AA\right)$ radiation. Intensity data were collected with $0.3^{\circ} \omega$-scans at a detector distance of $7 \mathrm{~cm}$. An initial unit cell determination was made using 60 frames with a 15 second exposure time. A hemisphere of data was collecting consisting of 1868 frames with an exposure time of 20 seconds/frame. The intensities were corrected for beam inhomogeneity, crystal decay and absorption with the program SADABS, ${ }^{1}$ which yielded $R_{\text {int }}=0.0542$ at $T_{\max }=0.65$ and $T_{\min }=0.29$.

A total of 142,114 reflections were measured at a maximum $2 \theta=49.42$, of which 25543 unique reflections were selected for $I>2 \sigma(I)$. Frame integration, including Lorenz polarization corrections and final unit cell parameters were made using SAINT+ software. ${ }^{2}$ Symmetry related and redundant reflections were averaged with the program XPREP. ${ }^{3}$ Systematic absences indicated that the crystal belongs to the space group $C 2 / C$ (No. 15) which led to $R_{\text {int }}=0.0782$ and $R_{\text {sigma }}=0.0724$. Structure solution was achieved using the direct methods program in SHELX97 (SHELXS) ${ }^{4}$ with the graphical interface X-SEED. ${ }^{5}$ Subsequent atoms were located from electron density difference maps. Hydrogen atoms were placed in idealized positions and were refined isotropically. A 
majority of the non-hydrogen atoms of the $[\mathrm{FeCl}]_{4}\left[\operatorname{Re}(\text { triphos })(\mathrm{CN})_{3}\right]_{4}$ molecule were refined anisotropically by full matrix least-squares methods (SHELXH). ${ }^{6}$

The primary coordination sphere of $\mathrm{Fe}(1)$ was found to exhibit substitutional disorder of the chloride ligand, which was disordered with one tetrahydrofuran ligand, and a methoxy- ligand that points towards the central cavity to compensate for the loss of negative charge. This disorder was modeled using 1:1 occupancy so that the coordinated THF molecule, $\mathrm{Cl}(1)$ and the methoxy- group all possess an occupancy of $50 \%$. The $\mathrm{Fe}(1)-\mathrm{Cl}(1)$ distance and the distances within the coordinated tetrahydrofuran were constrained to ideal distances. Carbon atoms comprising the two phenyl groups that exhibit positional disorder were refined isotropically. Solvent molecules were refined isotropically with varying occupancies as required. Distances and angles within the solvent molecules were constrained as necessary.

$[\mathrm{NiCl}]_{4}\left[\operatorname{Re}\left(\text { triphos)}(\mathrm{CN})_{3}\right]_{4}\right.$ (7): A light blue solution of anhydrous $\mathrm{Ni}^{\mathrm{II}} \mathrm{Cl}_{2}$ dissolved in warm acetonitrile layered upon a bright yellow solution of $\left[\mathrm{Et}_{4} \mathrm{~N}\right]\left[\operatorname{Re}(\right.$ triphos $\left.)(\mathrm{CN})_{3}\right]$ dissolved in acetonitrile in a $4 \mathrm{~mm}$ diameter glass tube yielded suitable single crystals for X-ray analysis. A dark brown plate of approximate dimensions $0.53 \times 0.39 \times 0.02 \mathrm{~mm}$ was affixed to a nylon loop using Paratone mineral oil and the data were measured at 110(2) K on a Siemens SMART CCD diffractometer with graphite monochromated Mo$\mathrm{K} \alpha\left(\lambda_{\alpha}=0.71073 \AA\right)$ radiation employing an APEX detector. Intensity data were collected with $0.3^{\circ} \omega$-scans at a sample-detector distance of $7 \mathrm{~cm}$. An initial unit cell determination was made using 60 frames with a 30 second exposure time. A hemisphere of data was collecting consisting of 1868 frames with an exposure time of 50 seconds/frame. The intensities were corrected for beam inhomogeneity, crystal decay and 
absorption with the program SADABS, ${ }^{1}$ which led to $R_{\mathrm{int}}=0.0609$, with a ratio of minimum to maximum apparent transmission of 0.53 . A total of 126428 reflections were measured at a maximum $2 \theta=49.42$, of which 17956 unique reflections were selected for $I>2 \sigma(I)$. Frame integration, including Lorenz polarization corrections and final unit cell parameters were made using SAINT + software. $^{2}$ Symmetry related and redundant reflections were averaged with the program XPREP. ${ }^{3}$ Systematic absences indicated that the crystal belongs to the space group $C 2 / C$ (No. 15) which led to $R_{\text {int }}=0.1680$ and $R_{\text {sigma }}$ $=0.2086$.

Structure solution was achieved using the direct methods program in SHELX97 $\left(\right.$ SHELXS) ${ }^{4}$ with the graphical interface X-SEED. ${ }^{5}$ Subsequent atoms were located from electron density difference maps. Hydrogen atoms were placed in idealized positions and refined isotropically. Non-hydrogen, non-solvent atoms were refined anisotropically by full matrix least-squares methods $(\mathrm{SHELXH}){ }^{6}$ Electron density located within the central cavity of the structure was successfully modeled as an acetonitrile molecule with a long $\mathrm{Ni}(1)-\mathrm{N}(1 \mathrm{I})$ bond $(\sim 2.340 \AA)$ and an occupancy of 0.25 . This molecule was refined isotropically, and the S.O.F. values assigned by variation of the site occupancies until acceptable isotropic thermal parameters were obtained. Bond lengths within the acetonitrile molecule were constrained to ideal values. Interstitial solvent molecules were refined isotropically and their occupancy factors adjusted and refined until they yielded acceptable thermal parameters in a similar fashion. Acetonitrile molecules N11S and N13S exhibit positional disorder and were modeled over two sites with occupancies of 1:1. Distances and angles within the solvent molecules were constrained as necessary. 
$[\mathrm{ZnCl}]_{4}\left[\operatorname{Re}(\text { triphos})(\mathrm{CN})_{3}\right]_{4}$ (8): Large, dark yellow blocks of excellent quality were obtained by layering a solution of $\left[\mathrm{Et}_{4} \mathrm{~N}\right]\left[\operatorname{Re}(\right.$ triphos $\left.)(\mathrm{CN})_{3}\right]$ dissolved in a mixture of acetonitrile and THF upon a solution of $\mathrm{ZnCl}_{2}$ (anhydrous) dissolved in a mixture of acetonitrile, THF, and a few drops methanol in a $4 \mathrm{~mm}$ diameter glass tube. The crystals grew over the course of 4 days. A dark yellow block of approximate dimensions $0.30 \times$ $0.25 \times 0.15 \mathrm{~mm}$ was affixed to a nylon loop using Paratone mineral oil and the data were measured at $100(2) \mathrm{K}$ on a Siemens SMART CCD diffractometer with graphite monochromated Mo-K $\alpha\left(\lambda_{\alpha}=0.71073 \AA\right)$ radiation employing an APEX detector. Intensity data were collected with $0.3^{\circ} \omega$-scans at a sample-detector distance of $7 \mathrm{~cm}$. An initial unit cell determination was made using 60 frames with a 20 second exposure time. A hemisphere of data was collecting consisting of 1868 frames with an exposure time of 20 seconds/frame. The intensities were corrected for beam inhomogeneity, crystal decay and absorption with the program SADABS, ${ }^{1}$ which led to $R_{\text {int }}=0.0294$, with a ratio of minimum to maximum apparent transmission of 0.85 . A total of 142837 reflections were measured at a maximum $2 \theta=49.42$, of which 27838 unique reflections were selected for $I>2 \sigma(I)$. Frame integration, including Lorenz polarization corrections and final unit cell parameters were made using SAINT + software. $^{2}$ Symmetry related and redundant reflections were averaged with the program XPREP. ${ }^{3}$ Systematic absences indicated that the crystal belongs to the space group $C 2 / c$ (No. 15) which led to $R_{\text {int }}=0.0434$ and $R_{\text {sigma }}$ $=0.0407$.

Structure solution was achieved using the direct methods program in SHELX97 $(\text { SHELXS })^{4}$ with the graphical interface X-SEED. ${ }^{5}$ Subsequent atoms were located from electron density difference maps. Hydrogen atoms were placed in idealized positions and 
refined isotropically. Non-hydrogen, non-solvent, non-disordered atoms were refined anisotropically by full matrix least-squares methods (SHELXH). ${ }^{6}$ Early on in the course of refinement a large peak of electron density ( 7.5 e- $)$ was discovered along the pseudo$\mathrm{C}_{3}$ axis linking $\operatorname{Re}(1)$ and $\mathrm{Zn}(1), \sim 1.6 \AA$ from $\mathrm{Zn}(1)$ toward the internal cavity of the cube. Assuming the peak arose as a result of an absorption problem due to anisotropic crystal shape, data collection was repeated several times - but the peak persisted across all the data sets. Small-ligand possibilities such as methoxide ( $\mathrm{Zn}-\mathrm{O}$ distance of $\sim 1.8$ $\AA^{[7]}$ ) and acetonitrile ( $\mathrm{Zn}-\mathrm{N}$ distance of $\sim 2.0 \AA^{[8]}$ ) were discounted based on the short bonding distance. Based on the large peak intensity, the site was modeled as a positional disorder between the external $\mathrm{Zn}(1)$ ion and the collapsed inward $\mathrm{Zn}(1 \mathrm{~A})$ ion. The occupancies of these sites were refined using the free variable, and the S.O.F.s were determined to be $20 \%$ for the internal $\mathrm{Zn}(1 \mathrm{~A})$ and $\mathrm{Cl}(1 \mathrm{~A})$, and $80 \%$ for the external $\mathrm{Zn}(1)$ and $\mathrm{Cl}(1)$. Several bond distances containing the internal $\mathrm{Zn}$ ion were constrained as necessary. One light molecule of methanol was located inside the central cavity in this structure and its occupany was refined to and modeled at $20 \%$. Slight disorder of this methanol molecule accounts for the slightly large thermal parameters determined for $\mathrm{Cl}(1 \mathrm{~A})$, which overlap in the model. Both components of the disorder associated with $\mathrm{Zn}(1)$ were refined anisotropically. One of the phenyl groups bound to $\mathrm{P}(1)$ exhibits a disorder over two positions. The occupancies of these groups were refined using free variables yielding site occupancy factors (S.O.F.s) of 35:65 for the two groups, which were then fixed. This approach was similarly taken in modeling the disorder of phenyl groups bound to $\mathrm{P}(4)$ and $\mathrm{P}(6)$ (both groups on $\mathrm{P}(6)$ ) leading to occupancies of 60:40 in these cases, which were also fixed. One phenyl group bound to $\mathrm{P}(3)$ exhibits positional 
disorder that was assigned a 1:1 occupancy. All the disordered components of these groups were refined isotropically.

Solvent molecules were refined isotropically and their occupancy factors manually adjusted then refined until they yielded acceptable thermal parameters. The THF molecule including O3S contains an additional small component of positional disorder which was not modeled. Distances and angles within the solvent molecules were constrained as necessary.

(1) SADABS 2.03, 2001, Sheldrick, G., Institüt für Anorganische Chemie der Universität, Tammanstrasse 4, Germany.

(2) SAINT+ 7.06, 2003, Bruker AXS, Inc., Madison, Wisconsin 53719.

(3) XPREP 6.07, 2000, Bruker AXS, Inc., Madison, Wisconsin 53719.

(4) SHELXS-97, 1997, Sheldrick, G., Institüt für Anorganische Chemie der Universität, Tammanstrasse 4, D-3400 Gottingen, Germany.

(5) Barbour, L. J. J. Supramol. Chem. 2001, 1, 189.

(6) SHELXL-97, 1997, Sheldrick, G., Institüt für Anorganische Chemie der Universität, Tammanstrasse 4, D-3400 Gottingen, Germany. 
S8. Selected bond distances and angles for $\left[\{\mathrm{FeCl}\} 3.5\left\{\mathrm{Fe}\left(\mathrm{OCH}_{3}\right)(\mathrm{THF})\right\}_{0.5-}\right.$

$\left\{\operatorname{Re}(\right.$ triphos $\left.\left.)(\mathrm{CN})_{3}\right\} 4\right]$ (5).

\begin{tabular}{|c|c|c|c|}
\hline Atoms & Distance / $\AA$ & Atoms & Distance / $\AA$ \\
\hline $\operatorname{Re}(1)-C(2)$ & $2.004(12)$ & $\mathrm{Fe}(1)-\mathrm{N}(10)$ & $1.911(15)$ \\
\hline $\operatorname{Re}(1)-C(1)$ & $2.017(12)$ & $\mathrm{Fe}(1)-\mathrm{N}(9)$ & $1.942(12)$ \\
\hline $\operatorname{Re}(1)-C(3)$ & $2.037(13)$ & $\mathrm{Fe}(1)-\mathrm{N}(4)$ & $1.942(12)$ \\
\hline $\operatorname{Re}(1)-\mathrm{P}(3)$ & $2.401(3)$ & $\mathrm{Fe}(1)-\mathrm{O}(1 \mathrm{~A})$ & $2.105(19)$ \\
\hline $\operatorname{Re}(1)-\mathrm{P}(1)$ & $2.409(3)$ & $\mathrm{Fe}(1)-\mathrm{Cl}(1 \mathrm{~A})$ & $2.243(5)$ \\
\hline $\operatorname{Re}(1)-\mathrm{P}(2)$ & $2.412(3)$ & $\mathrm{Fe}(1)-\mathrm{O}(2 \mathrm{~A})$ & $2.381(19)$ \\
\hline $\operatorname{Re}(2)-C(5)$ & $2.017(12)$ & $\mathrm{Fe}(2)-\mathrm{N}(7)$ & $1.905(10)$ \\
\hline $\operatorname{Re}(2)-C(6)$ & $2.037(14)$ & $\mathrm{Fe}(2)-\mathrm{N}(12)$ & $1.915(10)$ \\
\hline $\operatorname{Re}(2)-C(4)$ & $2.053(14)$ & $\mathrm{Fe}(2)-\mathrm{N}(1)$ & $1.929(10)$ \\
\hline $\operatorname{Re}(2)-\mathrm{P}(4)$ & $2.393(3)$ & $\mathrm{Fe}(2)-\mathrm{Cl}(2)$ & $2.209(4)$ \\
\hline $\operatorname{Re}(2)-\mathrm{P}(5)$ & $2.403(3)$ & $\mathrm{Fe}(3)-\mathrm{N}(5)$ & $1.922(10)$ \\
\hline $\operatorname{Re}(2)-P(6)$ & $2.408(3)$ & $\mathrm{Fe}(3)-\mathrm{N}(11)$ & $1.932(11)$ \\
\hline $\operatorname{Re}(3)-C(8)$ & $2.012(13)$ & $\mathrm{Fe}(3)-\mathrm{N}(2)$ & $1.944(11)$ \\
\hline $\operatorname{Re}(3)-C(7)$ & $2.016(14)$ & $\mathrm{Fe}(3)-\mathrm{Cl}(3)$ & $2.224(5)$ \\
\hline $\operatorname{Re}(3)-C(9)$ & $2.034(13)$ & $\mathrm{Fe}(4)-\mathrm{N}(6)$ & $1.918(11)$ \\
\hline $\operatorname{Re}(3)-\mathrm{P}(8)$ & $2.388(3)$ & $\mathrm{Fe}(4)-\mathrm{N}(8)$ & $1.926(12)$ \\
\hline $\operatorname{Re}(3)-P(9)$ & $2.390(3)$ & $\mathrm{Fe}(4)-\mathrm{N}(3)$ & $1.936(10)$ \\
\hline $\operatorname{Re}(3)-P(7)$ & $2.407(3)$ & $\mathrm{Fe}(4)-\mathrm{Cl}(4)$ & $2.221(5)$ \\
\hline $\operatorname{Re}(4)-C(11)$ & $1.995(13)$ & $\mathrm{C}(1)-\mathrm{N}(1)$ & $1.145(14)$ \\
\hline $\operatorname{Re}(4)-C(12)$ & $2.035(14)$ & $\mathrm{C}(2)-\mathrm{N}(2)$ & $1.169(15)$ \\
\hline $\operatorname{Re}(4)-C(10)$ & $2.036(16)$ & $\mathrm{C}(3)-\mathrm{N}(3)$ & $1.153(15)$ \\
\hline $\operatorname{Re}(4)-\mathrm{P}(10)$ & $2.389(3)$ & $\mathrm{C}(4)-\mathrm{N}(4)$ & $1.134(15)$ \\
\hline $\operatorname{Re}(4)-\mathrm{P}(12)$ & $2.395(4)$ & $\mathrm{C}(5)-\mathrm{N}(5)$ & $1.154(15)$ \\
\hline \multirow[t]{8}{*}{$\operatorname{Re}(4)-\mathrm{P}(11)$} & $2.400(4)$ & $\mathrm{C}(6)-\mathrm{N}(6)$ & $1.151(15)$ \\
\hline & & $\mathrm{C}(7)-\mathrm{N}(7)$ & $1.168(15)$ \\
\hline & & $\mathrm{C}(8)-\mathrm{N}(8)$ & $1.161(15)$ \\
\hline & & $\mathrm{C}(9)-\mathrm{N}(9)$ & $1.134(16)$ \\
\hline & & $\mathrm{C}(10)-\mathrm{N}(10)$ & $1.152(18)$ \\
\hline & & $\mathrm{C}(11)-\mathrm{N}(11)$ & $1.183(15)$ \\
\hline & & $\mathrm{C}(12)-\mathrm{N}(12)$ & $1.138(15)$ \\
\hline & & $\mathrm{O}(2 \mathrm{~A})-\mathrm{C}(5 \mathrm{~A})$ & $1.36(3)$ \\
\hline
\end{tabular}


S8. Selected bond distances and angles for $\left[\{\mathrm{FeCl}\} 3.5\left\{\mathrm{Fe}\left(\mathrm{OCH}_{3}\right)(\mathrm{THF})\right\}_{0.5-}\right.$

$\left\{\operatorname{Re}(\right.$ triphos $\left.\left.)(\mathrm{CN})_{3}\right\} 4\right](5)$.

\begin{tabular}{|c|c|c|c|}
\hline Atoms & Angle $/^{\circ}$ & Atoms & Angle / ${ }^{\circ}$ \\
\hline$C(2)-\operatorname{Re}(1)-C(1)$ & $85.1(4)$ & $\mathrm{C}(8)-\operatorname{Re}(3)-\mathrm{C}(7)$ & $85.4(5)$ \\
\hline$C(2)-\operatorname{Re}(1)-C(3)$ & $86.1(4)$ & $C(8)-\operatorname{Re}(3)-C(9)$ & $87.1(5)$ \\
\hline$C(1)-\operatorname{Re}(1)-C(3)$ & $86.2(5)$ & $C(7)-\operatorname{Re}(3)-C(9)$ & $85.3(5)$ \\
\hline $\mathrm{P}(1)-\operatorname{Re}(1)-\mathrm{P}(2)$ & $88.00(10)$ & $\mathrm{P}(8)-\operatorname{Re}(3)-\mathrm{P}(7)$ & $87.37(12)$ \\
\hline $\mathrm{P}(3)-\operatorname{Re}(1)-\mathrm{P}(1)$ & $86.10(10)$ & $\mathrm{P}(9)-\operatorname{Re}(3)-\mathrm{P}(7)$ & $87.31(11)$ \\
\hline $\mathrm{P}(3)-\operatorname{Re}(1)-\mathrm{P}(2)$ & $84.41(10)$ & $\mathrm{P}(8)-\operatorname{Re}(3)-\mathrm{P}(9)$ & $85.82(12)$ \\
\hline $\mathrm{C}(2)-\operatorname{Re}(1)-\mathrm{P}(3)$ & $93.8(3)$ & $\mathrm{C}(8)-\operatorname{Re}(3)-\mathrm{P}(8)$ & $178.1(4)$ \\
\hline $\mathrm{C}(1)-\operatorname{Re}(1)-\mathrm{P}(3)$ & $96.8(3)$ & $\mathrm{C}(7)-\operatorname{Re}(3)-\mathrm{P}(8)$ & $92.9(3)$ \\
\hline $\mathrm{C}(3)-\operatorname{Re}(1)-\mathrm{P}(3)$ & $177.0(3)$ & $\mathrm{C}(9)-\operatorname{Re}(3)-\mathrm{P}(8)$ & $93.6(4)$ \\
\hline $\mathrm{C}(2)-\operatorname{Re}(1)-\mathrm{P}(1)$ & $95.7(3)$ & $\mathrm{C}(8)-\operatorname{Re}(3)-\mathrm{P}(9)$ & $93.5(4)$ \\
\hline $\mathrm{C}(1)-\operatorname{Re}(1)-\mathrm{P}(1)$ & $176.9(3)$ & $\mathrm{C}(7)-\operatorname{Re}(3)-\mathrm{P}(9)$ & $95.7(3)$ \\
\hline $\mathrm{C}(3)-\operatorname{Re}(1)-\mathrm{P}(1)$ & $90.9(3)$ & $\mathrm{C}(9)-\operatorname{Re}(3)-\mathrm{P}(9)$ & $178.8(4)$ \\
\hline $\mathrm{C}(2)-\operatorname{Re}(1)-\mathrm{P}(2)$ & $175.8(3)$ & $\mathrm{C}(8)-\operatorname{Re}(3)-\mathrm{P}(7)$ & $94.4(3)$ \\
\hline $\mathrm{C}(1)-\operatorname{Re}(1)-\mathrm{P}(2)$ & $91.3(3)$ & $\mathrm{C}(7)-\operatorname{Re}(3)-\mathrm{P}(7)$ & $176.9(3)$ \\
\hline$C(3)-\operatorname{Re}(1)-P(2)$ & $95.9(3)$ & $\mathrm{C}(9)-\operatorname{Re}(3)-\mathrm{P}(7)$ & $91.6(4)$ \\
\hline$C(5)-\operatorname{Re}(2)-C(6)$ & $87.3(4)$ & $\mathrm{C}(11)-\operatorname{Re}(4)-\mathrm{C}(12)$ & $86.3(5)$ \\
\hline$C(5)-\operatorname{Re}(2)-C(4)$ & $86.8(5)$ & $C(11)-\operatorname{Re}(4)-C(10)$ & $86.6(5)$ \\
\hline$C(6)-\operatorname{Re}(2)-C(4)$ & $87.0(5)$ & $C(12)-\operatorname{Re}(4)-C(10)$ & $84.8(5)$ \\
\hline $\mathrm{P}(4)-\operatorname{Re}(2)-\mathrm{P}(5)$ & $86.99(11)$ & $\mathrm{P}(10)-\operatorname{Re}(4)-\mathrm{P}(12)$ & $88.60(11)$ \\
\hline $\mathrm{P}(4)-\operatorname{Re}(2)-\mathrm{P}(6)$ & $86.99(11)$ & $\mathrm{P}(10)-\operatorname{Re}(4)-\mathrm{P}(11)$ & $86.03(13)$ \\
\hline$P(5)-\operatorname{Re}(2)-P(6)$ & $86.75(11)$ & $\mathrm{P}(12)-\operatorname{Re}(4)-\mathrm{P}(11)$ & $86.11(12)$ \\
\hline$C(5)-\operatorname{Re}(2)-P(4)$ & $90.6(4)$ & $\mathrm{C}(11)-\operatorname{Re}(4)-\mathrm{P}(10)$ & $94.6(3)$ \\
\hline$C(6)-\operatorname{Re}(2)-P(4)$ & $95.4(3)$ & $\mathrm{C}(12)-\operatorname{Re}(4)-\mathrm{P}(10)$ & $92.6(3)$ \\
\hline$C(4)-\operatorname{Re}(2)-P(4)$ & $176.5(3)$ & $\mathrm{C}(10)-\operatorname{Re}(4)-\mathrm{P}(10)$ & $177.1(4)$ \\
\hline$C(5)-\operatorname{Re}(2)-P(5)$ & $176.9(4)$ & $\mathrm{C}(11)-\operatorname{Re}(4)-\mathrm{P}(12)$ & $91.1(4)$ \\
\hline$C(6)-\operatorname{Re}(2)-P(5)$ & $90.9(3)$ & $\mathrm{C}(12)-\mathrm{Re}(4)-\mathrm{P}(12)$ & $177.2(4)$ \\
\hline$C(4)-\operatorname{Re}(2)-P(5)$ & $95.6(4)$ & $\mathrm{C}(10)-\operatorname{Re}(4)-\mathrm{P}(12)$ & $94.0(4)$ \\
\hline$C(5)-\operatorname{Re}(2)-P(6)$ & $95.1(3)$ & $\mathrm{C}(11)-\operatorname{Re}(4)-\mathrm{P}(11)$ & $177.2(4)$ \\
\hline$C(6)-\operatorname{Re}(2)-P(6)$ & $176.6(3)$ & $\mathrm{C}(12)-\operatorname{Re}(4)-\mathrm{P}(11)$ & $96.4(4)$ \\
\hline $\mathrm{C}(4)-\operatorname{Re}(2)-\mathrm{P}(6)$ & $90.8(3)$ & $\mathrm{C}(10)-\operatorname{Re}(4)-\mathrm{P}(11)$ & $92.9(4)$ \\
\hline
\end{tabular}


S8. Selected bond distances and angles for $\left[\{\mathrm{FeCl}\} 3.5\left\{\mathrm{Fe}\left(\mathrm{OCH}_{3}\right)(\mathrm{THF})\right\}_{0.5-}\right.$

$\left\{\operatorname{Re}(\right.$ triphos $\left.\left.)(\mathrm{CN})_{3}\right\} 4\right](5)$.

\begin{tabular}{|c|c|c|c|}
\hline Atoms & Angle / ${ }^{\circ}$ & Atoms & Angle / ${ }^{\circ}$ \\
\hline $\mathrm{N}(10)-\mathrm{Fe}(1)-\mathrm{N}(9)$ & $119.1(6)$ & $\mathrm{N}(1)-\mathrm{C}(1)-\operatorname{Re}(1)$ & $175.1(11)$ \\
\hline $\mathrm{N}(10)-\mathrm{Fe}(1)-\mathrm{N}(4)$ & $118.4(6)$ & $\mathrm{C}(1)-\mathrm{N}(1)-\mathrm{Fe}(2)$ & $174.2(10)$ \\
\hline $\mathrm{N}(9)-\mathrm{Fe}(1)-\mathrm{N}(4)$ & $111.9(5)$ & $\mathrm{N}(2)-\mathrm{C}(2)-\operatorname{Re}(1)$ & $175.0(11)$ \\
\hline $\mathrm{N}(10)-\mathrm{Fe}(1)-\mathrm{O}(1 \mathrm{~A})$ & $95.3(8)$ & $\mathrm{C}(2)-\mathrm{N}(2)-\mathrm{Fe}(3)$ & $163.8(10)$ \\
\hline $\mathrm{N}(9)-\mathrm{Fe}(1)-\mathrm{O}(1 \mathrm{~A})$ & $111.4(9)$ & $N(3)-C(3)-\operatorname{Re}(1)$ & $177.8(11)$ \\
\hline $\mathrm{N}(4)-\mathrm{Fe}(1)-\mathrm{O}(1 \mathrm{~A})$ & $96.3(8)$ & $\mathrm{C}(3)-\mathrm{N}(3)-\mathrm{Fe}(4)$ & $166.9(10)$ \\
\hline $\mathrm{N}(10)-\mathrm{Fe}(1)-\mathrm{Cl}(1 \mathrm{~A})$ & $99.5(6)$ & $\mathrm{N}(4)-\mathrm{C}(4)-\operatorname{Re}(2)$ & $172.1(12)$ \\
\hline $\mathrm{N}(9)-\mathrm{Fe}(1)-\mathrm{Cl}(1 \mathrm{~A})$ & $101.3(5)$ & $\mathrm{C}(4)-\mathrm{N}(4)-\mathrm{Fe}(1)$ & $161.1(12)$ \\
\hline $\mathrm{N}(4)-\mathrm{Fe}(1)-\mathrm{Cl}(1 \mathrm{~A})$ & $102.3(5)$ & $\mathrm{N}(5)-\mathrm{C}(5)-\operatorname{Re}(2)$ & $177.1(11)$ \\
\hline $\mathrm{N}(10)-\mathrm{Fe}(1)-\mathrm{O}(2 \mathrm{~A})$ & $73.0(7)$ & $\mathrm{C}(5)-\mathrm{N}(5)-\mathrm{Fe}(3)$ & $167.4(11)$ \\
\hline $\mathrm{N}(9)-\mathrm{Fe}(1)-\mathrm{O}(2 \mathrm{~A})$ & $81.8(6)$ & $\mathrm{N}(6)-\mathrm{C}(6)-\operatorname{Re}(2)$ & $175.5(10)$ \\
\hline $\mathrm{N}(4)-\mathrm{Fe}(1)-\mathrm{O}(2 \mathrm{~A})$ & $82.7(6)$ & $\mathrm{C}(6)-\mathrm{N}(6)-\mathrm{Fe}(4)$ & $165.7(11)$ \\
\hline $\mathrm{C}(5 \mathrm{~A})-\mathrm{O}(2 \mathrm{~A})-\mathrm{Fe}(1)$ & $137.4(15)$ & $\mathrm{N}(7)-\mathrm{C}(7)-\operatorname{Re}(3)$ & $173.3(11)$ \\
\hline $\mathrm{N}(7)-\mathrm{Fe}(2)-\mathrm{N}(12)$ & $107.8(5)$ & $\mathrm{C}(7)-\mathrm{N}(7)-\mathrm{Fe}(2)$ & $171.6(10)$ \\
\hline $\mathrm{N}(7)-\mathrm{Fe}(2)-\mathrm{N}(1)$ & $106.2(4)$ & $\mathrm{N}(8)-\mathrm{C}(8)-\operatorname{Re}(3)$ & $174.5(11)$ \\
\hline $\mathrm{N}(12)-\mathrm{Fe}(2)-\mathrm{N}(1)$ & $104.0(4)$ & $\mathrm{C}(8)-\mathrm{N}(8)-\mathrm{Fe}(4)$ & $167.2(11)$ \\
\hline $\mathrm{N}(7)-\mathrm{Fe}(2)-\mathrm{Cl}(2)$ & $112.0(4)$ & $\mathrm{N}(9)-\mathrm{C}(9)-\operatorname{Re}(3)$ & $176.8(13)$ \\
\hline $\mathrm{N}(12)-\mathrm{Fe}(2)-\mathrm{Cl}(2)$ & $112.8(3)$ & $\mathrm{C}(9)-\mathrm{N}(9)-\mathrm{Fe}(1)$ & $162.5(12)$ \\
\hline $\mathrm{N}(1)-\mathrm{Fe}(2)-\mathrm{Cl}(2)$ & $113.5(3)$ & $\mathrm{N}(10)-\mathrm{C}(10)-\operatorname{Re}(4)$ & $174.6(15)$ \\
\hline $\mathrm{N}(5)-\mathrm{Fe}(3)-\mathrm{N}(11)$ & $104.7(5)$ & $\mathrm{C}(10)-\mathrm{N}(10)-\mathrm{Fe}(1)$ & $152.2(16)$ \\
\hline $\mathrm{N}(5)-\mathrm{Fe}(3)-\mathrm{N}(2)$ & $106.2(4)$ & $\mathrm{N}(11)-\mathrm{C}(11)-\operatorname{Re}(4)$ & $178.6(11)$ \\
\hline $\mathrm{N}(11)-\mathrm{Fe}(3)-\mathrm{N}(2)$ & $107.6(4)$ & $\mathrm{C}(11)-\mathrm{N}(11)-\mathrm{Fe}(3)$ & $167.0(10)$ \\
\hline $\mathrm{N}(5)-\mathrm{Fe}(3)-\mathrm{Cl}(3)$ & $113.5(3)$ & $\mathrm{N}(12)-\mathrm{C}(12)-\operatorname{Re}(4)$ & $174.4(11)$ \\
\hline $\mathrm{N}(11)-\mathrm{Fe}(3)-\mathrm{Cl}(3)$ & $113.4(3)$ & $\mathrm{C}(12)-\mathrm{N}(12)-\mathrm{Fe}(2)$ & $176.7(11)$ \\
\hline $\mathrm{N}(2)-\mathrm{Fe}(3)-\mathrm{Cl}(3)$ & $111.0(3)$ & & \\
\hline $\mathrm{N}(6)-\mathrm{Fe}(4)-\mathrm{N}(8)$ & $107.5(5)$ & & \\
\hline $\mathrm{N}(6)-\mathrm{Fe}(4)-\mathrm{N}(3)$ & $105.3(5)$ & & \\
\hline $\mathrm{N}(8)-\mathrm{Fe}(4)-\mathrm{N}(3)$ & $106.9(4)$ & & \\
\hline $\mathrm{N}(6)-\mathrm{Fe}(4)-\mathrm{Cl}(4)$ & $113.0(4)$ & & \\
\hline $\mathrm{N}(8)-\mathrm{Fe}(4)-\mathrm{Cl}(4)$ & $110.4(3)$ & & \\
\hline $\mathrm{N}(3)-\mathrm{Fe}(4)-\mathrm{Cl}(4)$ & $113.3(3)$ & & \\
\hline
\end{tabular}


S9. Molecular structure of $\left[\{\mathrm{NiCl}\}_{4}\left\{\operatorname{Re}(\text { triphos })(\mathrm{CN})_{3}\right\}_{4}\right](7)$.

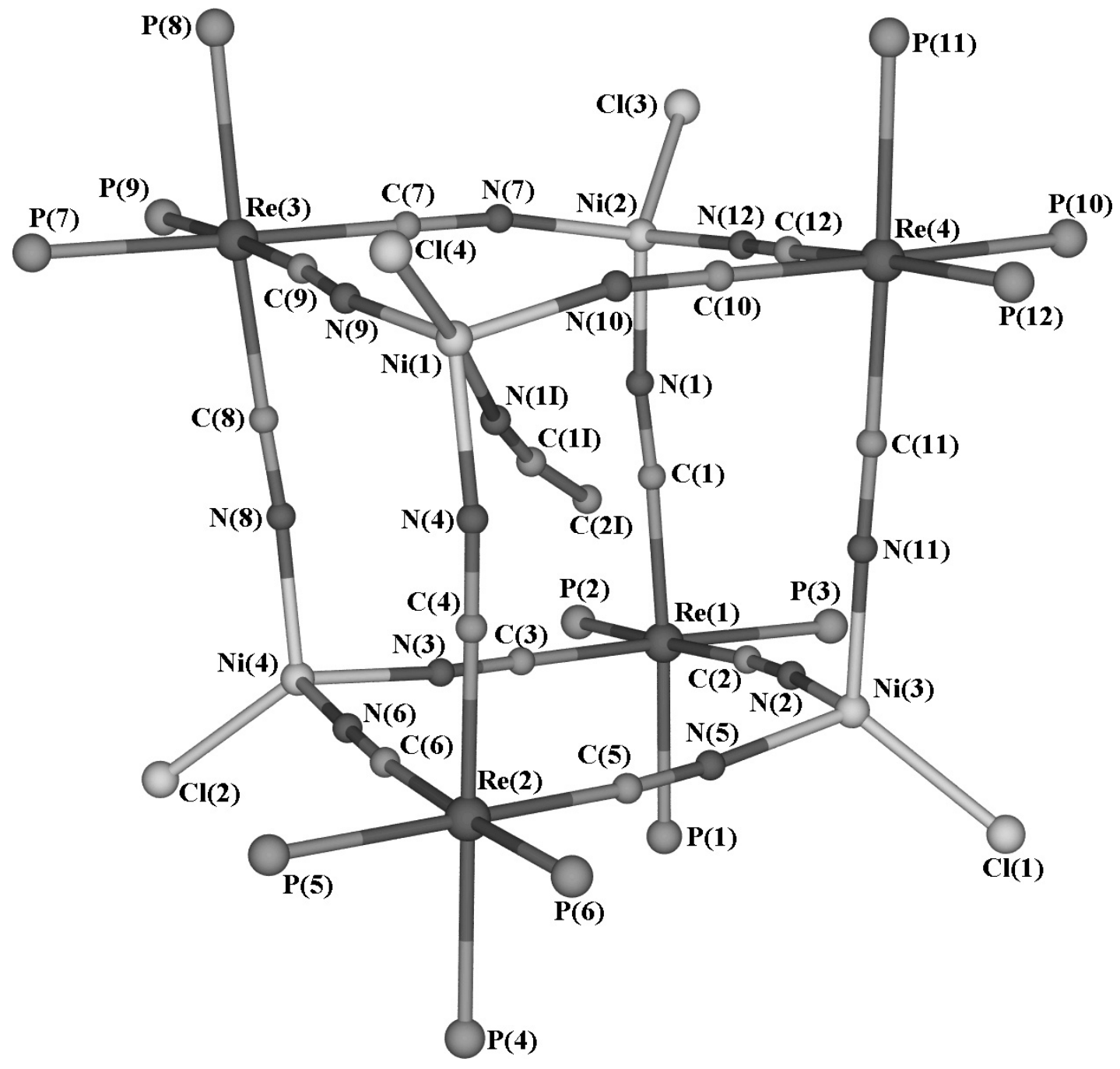

$\left[\left\{\mathrm{NiCl}_{4}\left\{\operatorname{Re}(\text { triphos})(\mathbf{C N})_{3}\right\}_{4}\right](7)\right.$ - Pertinent bond lengths and angles for 7 are listed in the table above. The Re-P and $\mathrm{Re}-\mathrm{C}$ bond distances are consistent with divalent $\mathrm{Re}$ ions in the molecule from distances ranging 2.412(5)-2.466(4) $\AA$ and 2.04(2)-2.10(2) $\AA$ respectively. The Ni-N (1.887(19)-1.966(15) $\AA$ ) and $\mathrm{Ni}-\mathrm{Cl}(2.205(6)-2.295(7) \AA)$ distances are consistent with divalent $\mathrm{Ni}-\mathrm{Cl},{ }^{1}$ and $\mathrm{Ni}-\mathrm{N}$ distances. The $\mathrm{C} \equiv \mathrm{N}$ distances in this structure range from 1.16(2)-1.21(2) A. One acetonitrile molecule with occupancy 
refined to 0.25 in position to interact with one of the $\mathrm{Ni}^{\mathrm{II}}$ centers resides in the central cavity of the cube. The Ni(1)-N(1I) bond distance between the metal and internal solvent molecule is long at $2.34(4) \AA$, as a survey of $\sim 40 \mathrm{Ni}^{\mathrm{II}}$ structures containing coordinated acetonitrile show an average bond distance of $\sim 2.07 \AA$. This indicates a weak Ni-N interaction as it is occurring in spite of the steric effects of the neighboring cyanide ligands. The weakened metal-ligand bonding accounts for the low occupancy of the acetonitrile molecule in this position.

The volume of the internal cavity of the structure of 7 is $\sim 43(3) \AA^{3}$ which is very close to the molecular volume (based on van der Waals radii) of one molecule of acetonitrile $\left(\sim 44 \AA^{3}\right)$; indicating this one acetonitrile molecule fills essentially all the allowable space within the cavity. If one considers the centroid defined by the positions of the eight metal atoms, it is possible to appreciate a compression of the structure along one of the pseudo- $\mathrm{C}_{3}$ axes in this structure, similar to those observed previously. The axis of compression lies along the pseudo- $\mathrm{C}_{3}$ formed by a vector drawn between $\operatorname{Re}(4)$ and $\mathrm{Ni}(4)$. The Re-Ni distances exhibit this compression ranging from 8.92-9.00 $\AA$ for three of the diagonal distances, while the forth distance along the diagonal defined by $\operatorname{Re}(4)$ and Ni(4) exhibits a distance of $8.76 \AA$.

(1) Arnold, D. I.; Cotton, F. A.; Maloney, D. J.; Matonic, J. H.; Murillo, C. A., Polyhedron 1996, 16, 133-141. 
S10. Selected bond distances for $\left[\{\mathrm{NiCl}\}_{4}\left\{\operatorname{Re}(\text { triphos })(\mathrm{CN})_{3}\right\}_{4}\right](7)$.

\begin{tabular}{|c|c|c|c|}
\hline Atoms & Distance / $\AA$ & Atoms & Distance / $\AA$ \\
\hline $\operatorname{Re}(1)-C(2)$ & $2.07(2)$ & $\mathrm{Ni}(1)-\mathrm{N}(9)$ & $1.887(19)$ \\
\hline $\operatorname{Re}(1)-C(3)$ & $2.08(2)$ & $\mathrm{Ni}(1)-\mathrm{N}(4)$ & $1.928(16)$ \\
\hline $\operatorname{Re}(1)-C(1)$ & $2.10(2)$ & Ni(1)-N(10) & $1.947(17)$ \\
\hline $\operatorname{Re}(1)-\mathrm{P}(2)$ & $2.422(4)$ & $\mathrm{Ni}(1)-\mathrm{Cl}(4)$ & $2.278(8)$ \\
\hline $\operatorname{Re}(1)-\mathrm{P}(3)$ & $2.428(4)$ & Ni(1)-N(1I) & $2.34(4)$ \\
\hline $\operatorname{Re}(1)-\mathrm{P}(1)$ & $2.466(4)$ & Ni(2)-N(12) & $1.900(17)$ \\
\hline $\operatorname{Re}(2)-C(5)$ & $2.07(2)$ & $\mathrm{Ni}(2)-\mathrm{N}(7)$ & $1.914(16)$ \\
\hline $\operatorname{Re}(2)-C(6)$ & $2.07(2)$ & $\mathrm{Ni}(2)-\mathrm{N}(1)$ & $1.950(17)$ \\
\hline $\operatorname{Re}(2)-C(4)$ & $2.09(2)$ & Ni(2)-Cl(3) & $2.295(7)$ \\
\hline $\operatorname{Re}(2)-\mathrm{P}(5)$ & $2.412(5)$ & $\mathrm{Ni}(3)-\mathrm{N}(2)$ & $1.946(14)$ \\
\hline $\operatorname{Re}(2)-P(6)$ & $2.421(5)$ & $\mathrm{Ni}(3)-\mathrm{N}(5)$ & $1.946(17)$ \\
\hline $\operatorname{Re}(2)-P(4)$ & $2.440(5)$ & Ni(3)-N(11) & $1.966(15)$ \\
\hline $\operatorname{Re}(3)-C(9)$ & $2.07(2)$ & $\mathrm{Ni}(3)-\mathrm{Cl}(1)$ & $2.224(5)$ \\
\hline $\operatorname{Re}(3)-C(7)$ & $2.08(2)$ & $\mathrm{Ni}(4)-\mathrm{N}(6)$ & $1.922(15)$ \\
\hline $\operatorname{Re}(3)-C(8)$ & $2.13(2)$ & Ni(4)-N(8) & $1.929(15)$ \\
\hline $\operatorname{Re}(3)-P(9)$ & $2.419(5)$ & $\mathrm{Ni}(4)-\mathrm{N}(3)$ & $1.953(15)$ \\
\hline $\operatorname{Re}(3)-P(7)$ & $2.427(5)$ & $\mathrm{Ni}(4)-\mathrm{Cl}(2)$ & $2.205(6)$ \\
\hline $\operatorname{Re}(3)-P(8)$ & $2.438(5)$ & $\mathrm{C}(1)-\mathrm{N}(1)$ & $1.19(2)$ \\
\hline $\operatorname{Re}(4)-C(10)$ & $2.04(2)$ & $\mathrm{C}(2)-\mathrm{N}(2)$ & $1.19(2)$ \\
\hline $\operatorname{Re}(4)-C(11)$ & $2.055(18)$ & $\mathrm{C}(3)-\mathrm{N}(3)$ & $1.17(2)$ \\
\hline $\operatorname{Re}(4)-C(12)$ & $2.08(2)$ & $C(4)-N(4)$ & $1.18(2)$ \\
\hline $\operatorname{Re}(4)-\mathrm{P}(10)$ & $2.438(5)$ & $C(5)-N(5)$ & $1.18(2)$ \\
\hline $\operatorname{Re}(4)-P(12)$ & $2.443(5)$ & $C(6)-N(6)$ & $1.20(2)$ \\
\hline $\operatorname{Re}(4)-\mathrm{P}(11)$ & $2.462(5)$ & $C(7)-N(7)$ & $1.17(2)$ \\
\hline $\mathrm{C}(2 \mathrm{I})-\mathrm{C}(1 \mathrm{I})$ & $1.471(5)$ & $\mathrm{C}(8)-\mathrm{N}(8)$ & $1.16(2)$ \\
\hline \multirow[t]{4}{*}{$\mathrm{C}(1 \mathrm{I})-\mathrm{N}(1 \mathrm{I})$} & $1.138(5)$ & $\mathrm{C}(9)-\mathrm{N}(9)$ & $1.21(2)$ \\
\hline & & $\mathrm{C}(10)-\mathrm{N}(10)$ & $1.19(2)$ \\
\hline & & $\mathrm{C}(11)-\mathrm{N}(11)$ & $1.213(19)$ \\
\hline & & $\mathrm{C}(12)-\mathrm{N}(12)$ & $1.19(2)$ \\
\hline
\end{tabular}


S10. Selected bond distances for $\left[\{\mathrm{NiCl}\}_{4}\left\{\operatorname{Re}(\text { triphos })(\mathrm{CN})_{3}\right\}_{4}\right](7)$.

\begin{tabular}{|c|c|c|c|}
\hline Atoms & Angle / ${ }^{\circ}$ & Atoms & Angle / ${ }^{\circ}$ \\
\hline $\mathrm{P}(2)-\operatorname{Re}(1)-\mathrm{P}(1)$ & $84.40(15)$ & $\mathrm{P}(7)-\operatorname{Re}(3)-\mathrm{P}(8)$ & $86.14(17)$ \\
\hline $\mathrm{P}(3)-\operatorname{Re}(1)-\mathrm{P}(1)$ & $87.87(14)$ & $\mathrm{P}(9)-\operatorname{Re}(3)-\mathrm{P}(7)$ & $86.57(17)$ \\
\hline $\mathrm{P}(2)-\operatorname{Re}(1)-\mathrm{P}(3)$ & $85.97(15)$ & $\mathrm{P}(9)-\operatorname{Re}(3)-\mathrm{P}(8)$ & $88.79(15)$ \\
\hline $\mathrm{C}(2)-\operatorname{Re}(1)-\mathrm{C}(3)$ & $84.7(6)$ & $C(9)-\operatorname{Re}(3)-C(7)$ & $87.8(7)$ \\
\hline$C(2)-\operatorname{Re}(1)-C(1)$ & $85.5(6)$ & $C(9)-\operatorname{Re}(3)-C(8)$ & $86.3(7)$ \\
\hline $\mathrm{C}(3)-\operatorname{Re}(1)-\mathrm{C}(1)$ & $85.4(6)$ & $C(7)-\operatorname{Re}(3)-C(8)$ & $83.8(7)$ \\
\hline $\mathrm{C}(2)-\operatorname{Re}(1)-\mathrm{P}(2)$ & $177.6(4)$ & $\mathrm{C}(9)-\operatorname{Re}(3)-\mathrm{P}(9)$ & $177.2(5)$ \\
\hline $\mathrm{C}(3)-\operatorname{Re}(1)-\mathrm{P}(2)$ & $97.7(4)$ & $\mathrm{C}(7)-\operatorname{Re}(3)-\mathrm{P}(9)$ & $92.9(5)$ \\
\hline $\mathrm{C}(1)-\operatorname{Re}(1)-\mathrm{P}(2)$ & $94.4(5)$ & $\mathrm{C}(8)-\operatorname{Re}(3)-\mathrm{P}(9)$ & $91.1(5)$ \\
\hline $\mathrm{C}(2)-\operatorname{Re}(1)-\mathrm{P}(3)$ & $91.7(4)$ & $\mathrm{C}(9)-\operatorname{Re}(3)-\mathrm{P}(7)$ & $92.8(5)$ \\
\hline $\mathrm{C}(3)-\operatorname{Re}(1)-\mathrm{P}(3)$ & $176.2(4)$ & $C(7)-\operatorname{Re}(3)-P(7)$ & $179.2(5)$ \\
\hline $\mathrm{C}(1)-\operatorname{Re}(1)-\mathrm{P}(3)$ & $95.5(5)$ & $\mathrm{C}(8)-\operatorname{Re}(3)-\mathrm{P}(7)$ & $96.8(5)$ \\
\hline $\mathrm{C}(2)-\operatorname{Re}(1)-\mathrm{P}(1)$ & $95.9(4)$ & $\mathrm{C}(9)-\operatorname{Re}(3)-\mathrm{P}(8)$ & $93.9(5)$ \\
\hline $\mathrm{C}(3)-\operatorname{Re}(1)-\mathrm{P}(1)$ & $91.4(4)$ & $\mathrm{C}(7)-\operatorname{Re}(3)-\mathrm{P}(8)$ & $93.2(5)$ \\
\hline $\mathrm{C}(1)-\operatorname{Re}(1)-\mathrm{P}(1)$ & $176.4(5)$ & $\mathrm{C}(8)-\operatorname{Re}(3)-\mathrm{P}(8)$ & $177.0(5)$ \\
\hline$P(5)-\operatorname{Re}(2)-P(6)$ & $86.73(17)$ & $\mathrm{P}(10)-\operatorname{Re}(4)-\mathrm{P}(12)$ & $86.37(15)$ \\
\hline$C(5)-\operatorname{Re}(2)-C(6)$ & $84.2(6)$ & $C(10)-\operatorname{Re}(4)-C(11)$ & $86.2(7)$ \\
\hline$C(5)-\operatorname{Re}(2)-C(4)$ & $87.1(7)$ & $C(10)-\operatorname{Re}(4)-C(12)$ & $88.2(7)$ \\
\hline$C(6)-\operatorname{Re}(2)-C(4)$ & $84.9(7)$ & $C(11)-\operatorname{Re}(4)-C(12)$ & $84.5(6)$ \\
\hline$C(5)-\operatorname{Re}(2)-P(5)$ & $177.5(5)$ & $\mathrm{C}(10)-\operatorname{Re}(4)-\mathrm{P}(10)$ & $178.0(5)$ \\
\hline $\mathrm{C}(6)-\operatorname{Re}(2)-\mathrm{P}(5)$ & $93.4(4)$ & $\mathrm{C}(11)-\operatorname{Re}(4)-\mathrm{P}(10)$ & $94.4(5)$ \\
\hline$C(4)-\operatorname{Re}(2)-P(5)$ & $93.5(5)$ & $C(12)-\operatorname{Re}(4)-P(10)$ & $90.0(5)$ \\
\hline$C(5)-\operatorname{Re}(2)-P(6)$ & $95.7(5)$ & $C(10)-\operatorname{Re}(4)-P(12)$ & $95.4(5)$ \\
\hline$C(6)-\operatorname{Re}(2)-P(6)$ & $176.9(5)$ & $\mathrm{C}(11)-\operatorname{Re}(4)-\mathrm{P}(12)$ & $92.7(4)$ \\
\hline $\mathrm{C}(4)-\operatorname{Re}(2)-\mathrm{P}(6)$ & $92.0(5)$ & $\mathrm{C}(12)-\operatorname{Re}(4)-\mathrm{P}(12)$ & $175.3(5)$ \\
\hline$C(5)-\operatorname{Re}(2)-P(4)$ & $93.3(5)$ & $\mathrm{C}(10)-\operatorname{Re}(4)-\mathrm{P}(11)$ & $91.6(5)$ \\
\hline$C(6)-\operatorname{Re}(2)-P(4)$ & $96.3(5)$ & $\mathrm{C}(11)-\operatorname{Re}(4)-\mathrm{P}(11)$ & $177.8(5)$ \\
\hline$C(4)-\operatorname{Re}(2)-P(4)$ & $178.7(5)$ & $\mathrm{C}(12)-\operatorname{Re}(4)-\mathrm{P}(11)$ & $95.9(5)$ \\
\hline
\end{tabular}


S10. Selected bond distances for $\left[\{\mathrm{NiCl}\}_{4}\left\{\operatorname{Re}(\text { triphos })(\mathrm{CN})_{3}\right\}_{4}\right](7)$.

\begin{tabular}{|c|c|c|c|}
\hline Atoms & Angle $/^{\circ}$ & Atoms & Angle $/^{\circ}$ \\
\hline $\mathrm{N}(9)-\mathrm{Ni}(1)-\mathrm{N}(4)$ & $108.3(7)$ & $\mathrm{N}(1)-\mathrm{C}(1)-\operatorname{Re}(1)$ & $175.7(17)$ \\
\hline N(9)-Ni(1)-N(10) & $104.9(7)$ & $\mathrm{C}(1)-\mathrm{N}(1)-\mathrm{Ni}(2)$ & $166.1(15)$ \\
\hline N(4)-Ni(1)-N(10) & $102.2(6)$ & $N(2)-C(2)-\operatorname{Re}(1)$ & $174.8(14)$ \\
\hline $\mathrm{N}(9)-\mathrm{Ni}(1)-\mathrm{Cl}(4)$ & $112.0(7)$ & $\mathrm{C}(2)-\mathrm{N}(2)-\mathrm{Ni}(3)$ & $174.2(13)$ \\
\hline $\mathrm{N}(4)-\mathrm{Ni}(1)-\mathrm{Cl}(4)$ & $113.6(5)$ & $N(3)-C(3)-\operatorname{Re}(1)$ & $177.7(15)$ \\
\hline N(10)-Ni(1)-Cl(4) & $115.1(5)$ & $\mathrm{C}(3)-\mathrm{N}(3)-\mathrm{Ni}(4)$ & $174.9(13)$ \\
\hline N(9)-Ni(1)-N(1I) & $63.0(14)$ & $N(4)-C(4)-\operatorname{Re}(2)$ & $178.2(18)$ \\
\hline N(4)-Ni(1)-N(1I) & $67.6(14)$ & $\mathrm{C}(4)-\mathrm{N}(4)-\mathrm{Ni}(1)$ & $170.3(16)$ \\
\hline $\mathrm{N}(10)-\mathrm{Ni}(1)-\mathrm{N}(1 \mathrm{I})$ & $69.1(13)$ & $N(5)-C(5)-\operatorname{Re}(2)$ & $174.9(15)$ \\
\hline $\mathrm{Cl}(4)-\mathrm{Ni}(1)-\mathrm{N}(1 \mathrm{I})$ & $174.6(13)$ & $\mathrm{C}(5)-\mathrm{N}(5)-\mathrm{Ni}(3)$ & $170.2(15)$ \\
\hline $\mathrm{N}(12)-\mathrm{Ni}(2)-\mathrm{N}(7)$ & $100.1(7)$ & $N(6)-C(6)-\operatorname{Re}(2)$ & $175.1(15)$ \\
\hline $\mathrm{N}(12)-\mathrm{Ni}(2)-\mathrm{N}(1)$ & $105.3(7)$ & $\mathrm{C}(6)-\mathrm{N}(6)-\mathrm{Ni}(4)$ & $177.0(14)$ \\
\hline $\mathrm{N}(7)-\mathrm{Ni}(2)-\mathrm{N}(1)$ & $106.4(6)$ & $N(7)-C(7)-\operatorname{Re}(3)$ & $178.8(17)$ \\
\hline $\mathrm{N}(12)-\mathrm{Ni}(2)-\mathrm{Cl}(3)$ & $116.6(5)$ & $\mathrm{C}(7)-\mathrm{N}(7)-\mathrm{Ni}(2)$ & $168.7(15)$ \\
\hline $\mathrm{N}(7)-\mathrm{Ni}(2)-\mathrm{Cl}(3)$ & $117.2(5)$ & $\mathrm{N}(8)-\mathrm{C}(8)-\operatorname{Re}(3)$ & $178.0(17)$ \\
\hline $\mathrm{N}(1)-\mathrm{Ni}(2)-\mathrm{Cl}(3)$ & $110.0(5)$ & $\mathrm{C}(8)-\mathrm{N}(8)-\mathrm{Ni}(4)$ & $174.0(15)$ \\
\hline $\mathrm{N}(2)-\mathrm{Ni}(3)-\mathrm{N}(5)$ & $102.4(6)$ & $N(9)-C(9)-\operatorname{Re}(3)$ & $173.4(18)$ \\
\hline $\mathrm{N}(2)-\mathrm{Ni}(3)-\mathrm{N}(11)$ & $99.9(6)$ & $\mathrm{C}(9)-\mathrm{N}(9)-\mathrm{Ni}(1)$ & $165.4(17)$ \\
\hline $\mathrm{N}(5)-\mathrm{Ni}(3)-\mathrm{N}(11)$ & $98.7(6)$ & $\mathrm{N}(10)-\mathrm{C}(10)-\operatorname{Re}(4)$ & $174.7(17)$ \\
\hline $\mathrm{N}(2)-\mathrm{Ni}(3)-\mathrm{Cl}(1)$ & $116.2(4)$ & $\mathrm{C}(10)-\mathrm{N}(10)-\mathrm{Ni}(1)$ & $168.4(15)$ \\
\hline $\mathrm{N}(5)-\mathrm{Ni}(3)-\mathrm{Cl}(1)$ & $115.0(4)$ & $\mathrm{N}(11)-\mathrm{C}(11)-\operatorname{Re}(4)$ & $178.3(13)$ \\
\hline N(11)-Ni(3)-Cl(1) & $121.5(4)$ & $\mathrm{C}(11)-\mathrm{N}(11)-\mathrm{Ni}(3)$ & $171.5(14)$ \\
\hline N(6)-Ni(4)-N(8) & $100.8(6)$ & $\mathrm{N}(12)-\mathrm{C}(12)-\operatorname{Re}(4)$ & $176.5(15)$ \\
\hline $\mathrm{N}(6)-\mathrm{Ni}(4)-\mathrm{N}(3)$ & $101.7(6)$ & $\mathrm{C}(12)-\mathrm{N}(12)-\mathrm{Ni}(2)$ & $166.2(15)$ \\
\hline $\mathrm{N}(8)-\mathrm{Ni}(4)-\mathrm{N}(3)$ & $96.9(6)$ & & \\
\hline $\mathrm{N}(6)-\mathrm{Ni}(4)-\mathrm{Cl}(2)$ & $115.5(5)$ & & \\
\hline $\mathrm{N}(8)-\mathrm{Ni}(4)-\mathrm{Cl}(2)$ & $121.2(5)$ & & \\
\hline $\mathrm{N}(3)-\mathrm{Ni}(4)-\mathrm{Cl}(2)$ & 117.3(4) & & \\
\hline
\end{tabular}


S11. Selected bond distances for $\left[\{\mathrm{ZnCl}\}_{4}\left\{\operatorname{Re}(\text { triphos })(\mathrm{CN})_{3}\right\}_{4}\right]$ (8).

\begin{tabular}{llll}
\hline Atoms & Distance $/ \AA$ & Atoms & Distance / \\
\hline $\operatorname{Re}(1)-\mathrm{C}(2)$ & $2.049(7)$ & $\mathrm{Zn}(1)-\mathrm{N}(4)$ & $1.992(6)$ \\
$\operatorname{Re}(1)-\mathrm{C}(3)$ & $2.067(7)$ & $\mathrm{Zn}(1)-\mathrm{N}(10)$ & $2.001(6)$ \\
$\operatorname{Re}(1)-\mathrm{C}(1)$ & $2.075(7)$ & $\mathrm{Zn}(1)-\mathrm{N}(9)$ & $2.010(6)$ \\
$\operatorname{Re}(1)-\mathrm{P}(1)$ & $2.4167(19)$ & $\mathrm{Zn}(1)-\mathrm{Cl}(1)$ & $2.205(2)$ \\
$\operatorname{Re}(1)-\mathrm{P}(2)$ & $2.4180(17)$ & $\mathrm{Zn}(2)-\mathrm{N}(7)$ & $1.973(8)$ \\
$\operatorname{Re}(1)-\mathrm{P}(3)$ & $2.4230(19)$ & $\mathrm{Zn}(2)-\mathrm{N}(12)$ & $1.983(7)$ \\
$\operatorname{Re}(2)-\mathrm{C}(5)$ & $2.053(7)$ & $\mathrm{Zn}(2)-\mathrm{N}(1)$ & $1.993(6)$ \\
$\operatorname{Re}(2)-\mathrm{C}(6)$ & $2.066(7)$ & $\mathrm{Zn}(2)-\mathrm{Cl}(2)$ & $2.214(2)$ \\
$\operatorname{Re}(2)-\mathrm{C}(4)$ & $2.074(8)$ & $\mathrm{Zn}(3)-\mathrm{N}(11)$ & $1.954(6)$ \\
$\operatorname{Re}(2)-\mathrm{P}(5)$ & $2.404(2)$ & $\mathrm{Zn}(3)-\mathrm{N}(5)$ & $1.966(6)$ \\
$\operatorname{Re}(2)-\mathrm{P}(4)$ & $2.4040(19)$ & $\mathrm{Zn}(3)-\mathrm{N}(2)$ & $1.983(6)$ \\
$\operatorname{Re}(2)-\mathrm{P}(6)$ & $2.409(2)$ & $\mathrm{Zn}(3)-\mathrm{Cl}(3)$ & $2.202(2)$ \\
$\operatorname{Re}(3)-\mathrm{C}(9)$ & $2.072(8)$ & $\mathrm{Zn}(4)-\mathrm{N}(6)$ & $1.982(6)$ \\
$\operatorname{Re}(3)-\mathrm{C}(8)$ & $2.077(7)$ & $\mathrm{Zn}(4)-\mathrm{N}(3)$ & $1.983(6)$ \\
$\operatorname{Re}(3)-\mathrm{C}(7)$ & $2.110(9)$ & $\mathrm{Zn}(4)-\mathrm{N}(8)$ & $1.993(6)$ \\
$\operatorname{Re}(3)-\mathrm{P}(9)$ & $2.4193(18)$ & $\mathrm{Zn}(4)-\mathrm{Cl}(4)$ & $2.217(2)$ \\
$\operatorname{Re}(3)-\mathrm{P}(7)$ & $2.423(2)$ & $\mathrm{C}(1)-\mathrm{N}(1)$ & $1.146(9)$ \\
$\operatorname{Re}(3)-\mathrm{P}(8)$ & $2.4231(19)$ & $\mathrm{N}(2)-\mathrm{C}(2)$ & $1.152(9)$ \\
$\operatorname{Re}(4)-\mathrm{C}(10)$ & $2.057(7)$ & $\mathrm{N}(3)-\mathrm{C}(3)$ & $1.158(9)$ \\
$\operatorname{Re}(4)-\mathrm{C}(12)$ & $2.057(8)$ & $\mathrm{C}(4)-\mathrm{N}(4)$ & $1.154(9)$ \\
$\operatorname{Re}(4)-\mathrm{C}(11)$ & $2.068(8)$ & $\mathrm{C}(5)-\mathrm{N}(5)$ & $1.156(9)$ \\
$\operatorname{Re}(4)-\mathrm{P}(12)$ & $2.4010(19)$ & $\mathrm{C}(6)-\mathrm{N}(6)$ & $1.146(9)$ \\
$\operatorname{Re}(4)-\mathrm{P}(10)$ & $2.406(2)$ & $\mathrm{C}(7)-\mathrm{N}(7)$ & $1.123(11)$ \\
$\operatorname{Re}(4)-\mathrm{P}(11)$ & $2.4098(19)$ & $\mathrm{C}(8)-\mathrm{N}(8)$ & $1.141(9)$ \\
$\mathrm{N}(10)-\mathrm{Zn}(1 \mathrm{~A})$ & $1.965(8)$ & $\mathrm{C}(9)-\mathrm{N}(9)$ & $1.144(9)$ \\
$\mathrm{N}(4)-\mathrm{Zn}(1 \mathrm{~A})$ & $1.901(8)$ & $\mathrm{C}(10)-\mathrm{N}(10)$ & $1.151(9)$ \\
$\mathrm{N}(9)-\mathrm{Zn}(1 \mathrm{~A})$ & $1.994(8)$ & $\mathrm{C}(11)-\mathrm{N}(11)$ & $1.150(9)$ \\
$\mathrm{Cl}(1 \mathrm{~A})-\mathrm{Zn}(1 \mathrm{~A})$ & $2.242(4)$ & $\mathrm{C}(12)-\mathrm{N}(12)$ & $1.156(9)$ \\
\hline & & &
\end{tabular}


S11. Selected bond distances for $\left[\{\mathrm{ZnCl}\}_{4}\left\{\operatorname{Re}(\text { triphos })(\mathrm{CN})_{3}\right\}_{4}\right]$ (8).

\begin{tabular}{|c|c|c|c|}
\hline Atoms & Angle $/^{\circ}$ & Atoms & Angle $/^{\circ}$ \\
\hline$C(2)-\operatorname{Re}(1)-C(3)$ & $84.3(3)$ & $C(9)-\operatorname{Re}(3)-C(8)$ & $85.9(3)$ \\
\hline$C(2)-\operatorname{Re}(1)-C(1)$ & $84.7(3)$ & $C(9)-\operatorname{Re}(3)-C(7)$ & $85.3(3)$ \\
\hline$C(3)-\operatorname{Re}(1)-C(1)$ & $85.6(3)$ & $C(8)-\operatorname{Re}(3)-C(7)$ & $85.0(2)$ \\
\hline $\mathrm{C}(2)-\operatorname{Re}(1)-\mathrm{P}(1)$ & $97.3(2)$ & $\mathrm{C}(9)-\operatorname{Re}(3)-\mathrm{P}(9)$ & $175.2(2)$ \\
\hline $\mathrm{C}(3)-\operatorname{Re}(1)-\mathrm{P}(1)$ & $94.18(19)$ & $\mathrm{C}(8)-\operatorname{Re}(3)-\mathrm{P}(9)$ & $89.60(19)$ \\
\hline $\mathrm{C}(1)-\operatorname{Re}(1)-\mathrm{P}(1)$ & 177.91(19) & $\mathrm{C}(7)-\operatorname{Re}(3)-\mathrm{P}(9)$ & $95.82(18)$ \\
\hline $\mathrm{C}(2)-\operatorname{Re}(1)-\mathrm{P}(2)$ & $176.2(2)$ & $\mathrm{C}(9)-\operatorname{Re}(3)-\mathrm{P}(7)$ & $91.57(19)$ \\
\hline $\mathrm{C}(3)-\operatorname{Re}(1)-\mathrm{P}(2)$ & $96.23(19)$ & $\mathrm{C}(8)-\operatorname{Re}(3)-\mathrm{P}(7)$ & $96.97(18)$ \\
\hline $\mathrm{C}(1)-\operatorname{Re}(1)-\mathrm{P}(2)$ & $91.55(18)$ & $\mathrm{C}(7)-\operatorname{Re}(3)-\mathrm{P}(7)$ & $176.18(18)$ \\
\hline $\mathrm{P}(1)-\operatorname{Re}(1)-\mathrm{P}(2)$ & $86.40(6)$ & $\mathrm{P}(9)-\operatorname{Re}(3)-\mathrm{P}(7)$ & $87.49(6)$ \\
\hline $\mathrm{C}(2)-\operatorname{Re}(1)-\mathrm{P}(3)$ & 90.93(19) & $\mathrm{C}(9)-\operatorname{Re}(3)-\mathrm{P}(8)$ & $98.0(2)$ \\
\hline $\mathrm{C}(3)-\operatorname{Re}(1)-\mathrm{P}(3)$ & $174.89(18)$ & $\mathrm{C}(8)-\operatorname{Re}(3)-\mathrm{P}(8)$ & $174.76(18)$ \\
\hline $\mathrm{C}(1)-\operatorname{Re}(1)-\mathrm{P}(3)$ & $95.84(18)$ & $\mathrm{C}(7)-\operatorname{Re}(3)-\mathrm{P}(8)$ & $91.86(18)$ \\
\hline $\mathrm{P}(1)-\operatorname{Re}(1)-\mathrm{P}(3)$ & $84.52(6)$ & $\mathrm{P}(9)-\operatorname{Re}(3)-\mathrm{P}(8)$ & $86.56(6)$ \\
\hline $\mathrm{P}(2)-\operatorname{Re}(1)-\mathrm{P}(3)$ & $88.64(6)$ & $\mathrm{P}(7)-\operatorname{Re}(3)-\mathrm{P}(8)$ & $86.43(6)$ \\
\hline$C(5)-\operatorname{Re}(2)-C(6)$ & $85.9(3)$ & $C(10)-\operatorname{Re}(4)-C(12)$ & $85.8(3)$ \\
\hline$C(5)-\operatorname{Re}(2)-C(4)$ & $83.8(3)$ & $C(10)-\operatorname{Re}(4)-C(11)$ & $84.1(3)$ \\
\hline$C(6)-\operatorname{Re}(2)-C(4)$ & $86.1(3)$ & $C(12)-\operatorname{Re}(4)-C(11)$ & $84.2(3)$ \\
\hline$C(5)-\operatorname{Re}(2)-P(5)$ & $177.2(2)$ & $\mathrm{C}(10)-\operatorname{Re}(4)-\mathrm{P}(12)$ & $94.9(2)$ \\
\hline$C(6)-\operatorname{Re}(2)-P(5)$ & $91.43(19)$ & $\mathrm{C}(12)-\operatorname{Re}(4)-\mathrm{P}(12)$ & $177.0(2)$ \\
\hline$C(4)-\operatorname{Re}(2)-P(5)$ & $95.3(2)$ & $\mathrm{C}(11)-\operatorname{Re}(4)-\mathrm{P}(12)$ & $93.00(19)$ \\
\hline$C(5)-\operatorname{Re}(2)-P(4)$ & $91.8(2)$ & $C(10)-\operatorname{Re}(4)-P(10)$ & $179.2(2)$ \\
\hline $\mathrm{C}(6)-\operatorname{Re}(2)-\mathrm{P}(4)$ & $93.75(19)$ & $\mathrm{C}(12)-\operatorname{Re}(4)-\mathrm{P}(10)$ & $93.43(19)$ \\
\hline$C(4)-\operatorname{Re}(2)-P(4)$ & $175.6(2)$ & $\mathrm{C}(11)-\operatorname{Re}(4)-\mathrm{P}(10)$ & $96.02(19)$ \\
\hline$P(5)-\operatorname{Re}(2)-P(4)$ & $89.07(6)$ & $\mathrm{P}(12)-\operatorname{Re}(4)-\mathrm{P}(10)$ & $85.84(7)$ \\
\hline$C(5)-\operatorname{Re}(2)-P(6)$ & $96.5(2)$ & $\mathrm{C}(10)-\operatorname{Re}(4)-\mathrm{P}(11)$ & $92.3(2)$ \\
\hline$C(6)-\operatorname{Re}(2)-P(6)$ & 177.68(19) & $\mathrm{C}(12)-\operatorname{Re}(4)-\mathrm{P}(11)$ & $95.3(2)$ \\
\hline$C(4)-\operatorname{Re}(2)-P(6)$ & $94.3(2)$ & $\mathrm{C}(11)-\operatorname{Re}(4)-\mathrm{P}(11)$ & $176.30(19)$ \\
\hline$P(5)-\operatorname{Re}(2)-P(6)$ & $86.26(7)$ & $\mathrm{P}(12)-\operatorname{Re}(4)-\mathrm{P}(11)$ & $87.55(7)$ \\
\hline $\mathrm{P}(4)-\operatorname{Re}(2)-\mathrm{P}(6)$ & $86.01(8)$ & $\mathrm{P}(10)-\operatorname{Re}(4)-\mathrm{P}(11)$ & $87.67(7)$ \\
\hline
\end{tabular}


S11. Selected bond distances for $\left[\{\mathrm{ZnCl}\}_{4}\left\{\operatorname{Re}(\text { triphos })(\mathrm{CN})_{3}\right\}_{4}\right]$ (8).

\begin{tabular}{|c|c|c|c|}
\hline Atoms & Angles $/^{\circ}$ & Atoms & Angles / ${ }^{\circ}$ \\
\hline $\mathrm{N}(4)-\mathrm{Zn}(1)-\mathrm{N}(10)$ & $104.2(3)$ & $\mathrm{N}(1)-\mathrm{C}(1)-\operatorname{Re}(1)$ & $178.2(6)$ \\
\hline $\mathrm{N}(4)-\mathrm{Zn}(1)-\mathrm{N}(9)$ & 103.2(3) & $\mathrm{C}(1)-\mathrm{N}(1)-\mathrm{Zn}(2)$ & $167.9(6)$ \\
\hline $\mathrm{N}(10)-\mathrm{Zn}(1)-\mathrm{N}(9)$ & $101.2(2)$ & $\mathrm{N}(2)-\mathrm{C}(2)-\operatorname{Re}(1)$ & $176.2(6)$ \\
\hline $\mathrm{N}(4)-\mathrm{Zn}(1)-\mathrm{Cl}(1)$ & 115.81(19) & $\mathrm{C}(2)-\mathrm{N}(2)-\mathrm{Zn}(3)$ & $173.2(6)$ \\
\hline $\mathrm{N}(10)-\mathrm{Zn}(1)-\mathrm{Cl}(1)$ & 115.16(19) & $\mathrm{N}(3)-\mathrm{C}(3)-\operatorname{Re}(1)$ & $175.4(6)$ \\
\hline $\mathrm{N}(9)-\mathrm{Zn}(1)-\mathrm{Cl}(1)$ & $115.44(19)$ & $\mathrm{C}(3)-\mathrm{N}(3)-\mathrm{Zn}(4)$ & $165.8(5)$ \\
\hline $\mathrm{N}(7)-\mathrm{Zn}(2)-\mathrm{N}(12)$ & $102.8(3)$ & $N(4)-C(4)-\operatorname{Re}(2)$ & $175.2(7)$ \\
\hline $\mathrm{N}(7)-\mathrm{Zn}(2)-\mathrm{N}(1)$ & $101.5(3)$ & $\mathrm{C}(4)-\mathrm{N}(4)-\mathrm{Zn}(1)$ & $167.3(6)$ \\
\hline $\mathrm{N}(12)-\mathrm{Zn}(2)-\mathrm{N}(1)$ & $103.5(2)$ & $\mathrm{C}(4)-\mathrm{N}(4)-\mathrm{Zn}(1 \mathrm{~A})$ & $123.5(6)$ \\
\hline $\mathrm{N}(7)-\mathrm{Zn}(2)-\mathrm{Cl}(2)$ & $116.8(2)$ & $N(5)-C(5)-\operatorname{Re}(2)$ & $176.7(6)$ \\
\hline $\mathrm{N}(12)-\mathrm{Zn}(2)-\mathrm{Cl}(2)$ & $114.70(18)$ & $\mathrm{C}(5)-\mathrm{N}(5)-\mathrm{Zn}(3)$ & $175.2(6)$ \\
\hline $\mathrm{N}(1)-\mathrm{Zn}(2)-\mathrm{Cl}(2)$ & $115.63(18)$ & $N(6)-C(6)-\operatorname{Re}(2)$ & $177.6(6)$ \\
\hline $\mathrm{N}(11)-\mathrm{Zn}(3)-\mathrm{N}(5)$ & $104.6(3)$ & $\mathrm{C}(6)-\mathrm{N}(6)-\mathrm{Zn}(4)$ & $168.7(6)$ \\
\hline $\mathrm{N}(11)-\mathrm{Zn}(3)-\mathrm{N}(2)$ & $103.2(3)$ & $N(7)-C(7)-\operatorname{Re}(3)$ & $178.6(6)$ \\
\hline $\mathrm{N}(5)-\mathrm{Zn}(3)-\mathrm{N}(2)$ & $101.6(2)$ & $C(7)-N(7)-Z n(2)$ & $166.1(7)$ \\
\hline $\mathrm{N}(11)-\mathrm{Zn}(3)-\mathrm{Cl}(3)$ & 114.1(2) & $N(8)-C(8)-\operatorname{Re}(3)$ & $178.4(6)$ \\
\hline $\mathrm{N}(5)-\mathrm{Zn}(3)-\mathrm{Cl}(3)$ & $115.65(19)$ & $\mathrm{C}(8)-\mathrm{N}(8)-\mathrm{Zn}(4)$ & $166.0(6)$ \\
\hline $\mathrm{N}(2)-\mathrm{Zn}(3)-\mathrm{Cl}(3)$ & $115.87(19)$ & $N(9)-C(9)-\operatorname{Re}(3)$ & $177.5(6)$ \\
\hline $\mathrm{N}(6)-\mathrm{Zn}(4)-\mathrm{N}(3)$ & $104.2(2)$ & $\mathrm{C}(9)-\mathrm{N}(9)-\mathrm{Zn}(1)$ & $168.2(6)$ \\
\hline $\mathrm{N}(6)-\mathrm{Zn}(4)-\mathrm{N}(8)$ & $100.7(2)$ & $\mathrm{C}(9)-\mathrm{N}(9)-\mathrm{Zn}(1 \mathrm{~A})$ & $127.6(6)$ \\
\hline $\mathrm{N}(3)-\mathrm{Zn}(4)-\mathrm{N}(8)$ & $102.8(2)$ & $N(10)-C(10)-\operatorname{Re}(4)$ & $177.8(7)$ \\
\hline $\mathrm{N}(6)-\mathrm{Zn}(4)-\mathrm{Cl}(4)$ & $115.75(18)$ & $C(10)-N(10)-Z n(1 A)$ & $130.4(6)$ \\
\hline $\mathrm{N}(3)-\mathrm{Zn}(4)-\mathrm{Cl}(4)$ & $114.70(18)$ & $\mathrm{C}(10)-\mathrm{N}(10)-\mathrm{Zn}(1)$ & $173.0(6)$ \\
\hline \multirow[t]{4}{*}{ N(8)-Zn(4)-Cl(4) } & $116.76(18)$ & $\mathrm{N}(11)-\mathrm{C}(11)-\operatorname{Re}(4)$ & $175.0(6)$ \\
\hline & & $\mathrm{C}(11)-\mathrm{N}(11)-\mathrm{Zn}(3)$ & $173.2(6)$ \\
\hline & & $\mathrm{N}(12)-\mathrm{C}(12)-\operatorname{Re}(4)$ & $175.8(6)$ \\
\hline & & $\mathrm{C}(12)-\mathrm{N}(12)-\mathrm{Zn}(2)$ & $165.0(6)$ \\
\hline
\end{tabular}




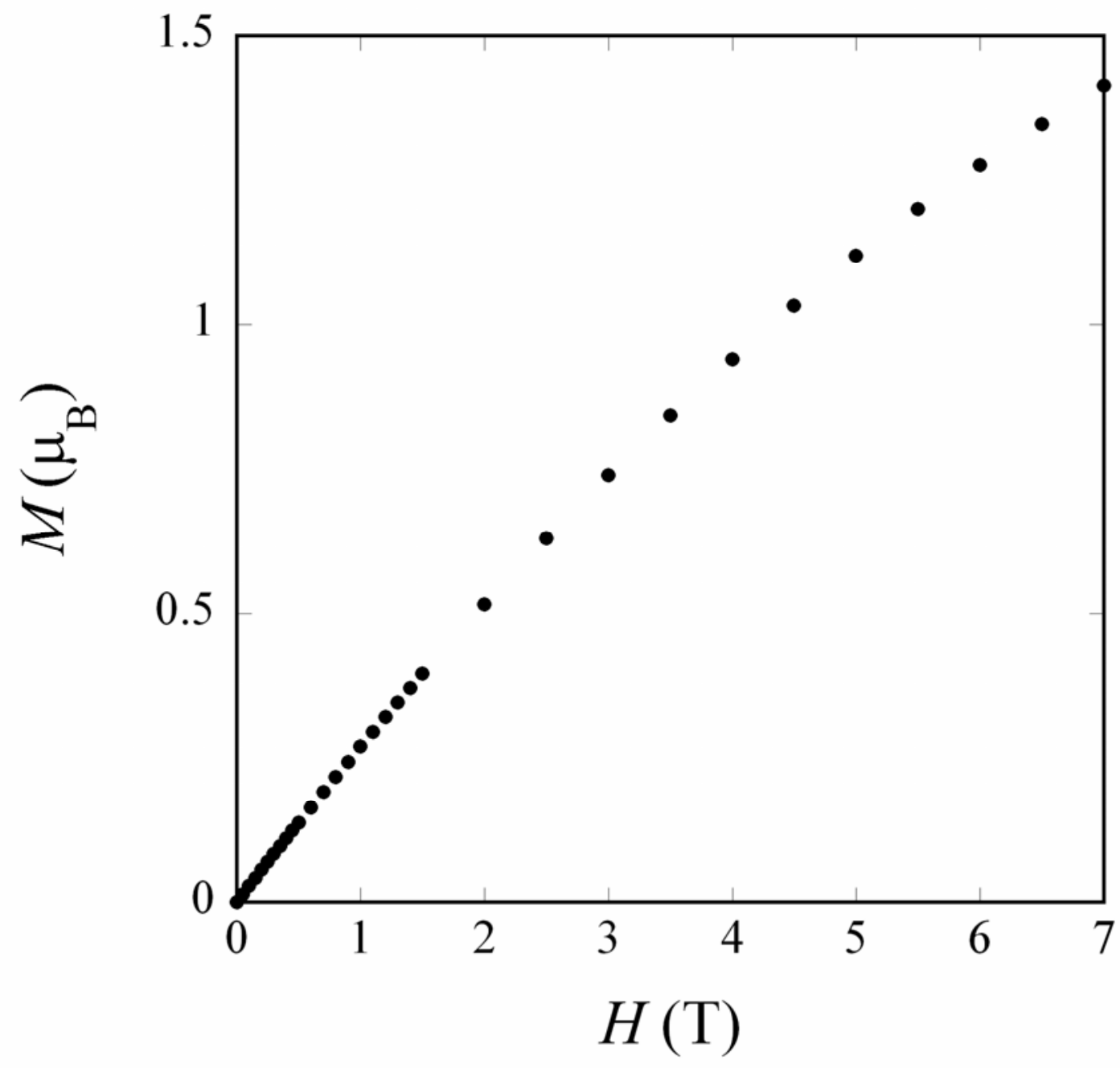

S12: Field dependent magnetization data for $\left[\{\mathrm{ZnCl}\}_{4}\left\{\operatorname{Re}(\text { triphos })(\mathrm{CN})_{3}\right\}_{4}\right]$ (8) collected at $1.8 \mathrm{~K}$. 